\title{
MORATORY LEGISLATION RELATING TO BILLS AND NOTES AND THE CONFLICT OF LAWS
}

\author{
ERNEST G. LORENZEN \\ Professor of Law, Yale University
}

In Roman law a debtor might obtain through a rescript of the emperor an extension of time (moratorium) within which to pay a debt, upon giving security. ${ }^{2}$ Following the example of the Roman law a number of the modern continental codes authorized the granting of a judicial moratorium under certain conditions. Such legislation existed also with respect to bills and notes. ${ }^{3}$ In most of the countries such a power is no longer generally vested in the Courts. ${ }^{*}$ In times of great emergency, however, it is conferred upon them for a limited period of time. The present world war has also given rise to legislation of this kind.

Emergency legislation of a different sort granting time to a debtor to pay has been passed in various countries as the result of wars, revolutions, floods and other conditions vitally affecting the economic situation of the country or a particular section thereof. 5 At times it has taken the form of a general moratorium which postpones all pay-

${ }^{1} \mathrm{~A}$ bibliography of the special literature on moratory legislation and the conflict of laws will be found in Appendix D, infra.

${ }^{2}$ Code I, 19, 2, 4 .

${ }^{3}$ I Pöhl, Darstellung des gemeinen deutschen und des hamburgischen Handelsrechts, 385. See also Bills of Exchange Act of Vienna of Sept. I0, 1717, art. 51 (I Siege1,-Corpus Juris Cambialis, 1742, p. I18); Bills of Exchange Act of Silesia of 1738, art. 38, sec. 2 (Siegel, op. cit. 313); Bills of Exchange Act of Brunswick of August I, 1715, art. 56 (Siegel, op. cit. 26I) ; Allgemeine Landrecht of Prussia, I, tit. 16, sec. 356, which was changed by sec. 14, no. 4, of the Introductory Law to the Code of Civil Procedure (I Förster-Eccius, Theorie und Praxis des heutigen gemeinen preussischen Privatrechts, sec. 91, no. 42).

${ }^{4}$ In Austria such power was taken from the courts through sec. 353 of the Allgemeine Gerichtsordnung, of May $\mathrm{r}, \mathrm{r} 78 \mathrm{r}$.

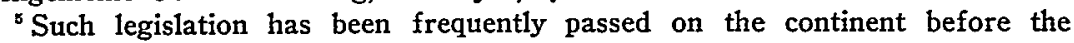
present war, especially in Italy. Attention may be called to the following:

Austria. Decrees of 1848 and I866 (mentioned by Fick, p. II).

France. Decrees of 1830 and 1848 . See Duvergier, Collection complète des lois, decrets, etc., 1830, p. 155; 1848, pp. 61, 63, 72, 125, 134, 366.

Germany. See Prussian decree of 1854 , made at the time of the destruction of the city of Memel by fire (mentioned by Swoboda in Oesterreichische Gerichtszeitung, 1870, p. 290) and the decree of 1870 with respect to Alsace-Lorraine (mentioned by Fick, Ueber internationales Wechselrecht in Beziehung auf Fristbestimmungen, insbesondere dif französischen Wechsel-Moratoriumsgesetze und Dekrete, II.

Italy. Decrees of I848, I849, I859, I866, I870. See also the later decrees of 
ments for a designated period, excepting those specifically enumerated by the law. More frequently it has had a more limited scope and has applied only to the payment of bills and notes. In case of war special moratory legislation is frequently passed for the benefit of members of the army and the navy; this is intended to protect the interests of those in the service of their country who are consequently unable to look after their affairs at home. Such legislation often prohibits suits against them while they are in active service and modifies the ordinary statutes of limitations.

Moratory legislation in its various forms may give rise to a multitude of questions in the conflict of laws. The present article proposes to consider the moratory legislation of the various countries enacted during the present war so far as it has attempted to postpone either directly ar indirectly the time of payment of bills, notes and checks. The international character of such instruments makes the consideration of this problem of the greatest practical importance.

The moratory legislation of the principal countries enacted during the present war and relating to bills and notes, has taken a very considerable variety of forms. It, as well as the French legislation of I870-I87I, will be found in its detail in Appendix A, infra. The existing Belgian legislation follows the French decree of August ro, I870, in postponing the "time for protesting." The original decrees of France and of Germany speak likewise of the postponement of the "time for protesting," but the subsequent decrees postpone the day of "maturity." In England the "due date" of bills re-accepted at the time of original maturity was extended. Italy from the beginning postponed the "maturity." In Austria the "time for payment" (Zahlungszeit) $^{6}$ was postponed. The original decree of the Swiss Federal Council granted thirty "days of grace." Subsequently the principle of reciprocity was adopted. Interest for the time during which the holder was deprived of his money on account of the extensions granted was allowed by the legislation of all countries except Switzerland. Some of the decrees extended the time within which the protest might be made or suit brought.

1894, 1909 and I9I5 (mentioned by Ghiron, Moratorie e regressi nel diritto internazionale privato, Rivista de diritto internazionale, 1915, p. I52).

Szeritzerland. See decree of Oct. 12, I846, by the provisional government for the canton of Geneva (see Recueil authentique des lois et actes du gouvernement et de la république et canton de Genève, 1846, p. 207), and decree of 1870 (mentioned -in the opinion of the Court of Appeals of Geneva in its decision of Mar. 25, 1872); see Journal de Genève, Apr. Io, I872, no. 84; Sirey, 1872, 2, 217; Belgique judiciaire, 1872, col. 524; 7 Annali, I, 47.

"In Austria and Germany a distinction is often made between "maturity" (Fälligkeit) and "time of payment" (Zahlungstag). If a bill or note falls due on a Sunday that day would constitute its day of maturity. The day of payment would be the succeeding business day. 
The principal problem to be solved is the following: Is the moratory legislation of the above countries relating to bills and notes which are payable therein effective with respect-to persons who became parties to such instruments in the United States? And if it is effective, what is its effect?

The problem thus presented aroused an international interest after the Franco-Prussian War. The validity of the French moratory legislation relating to bills and notes came at that time before the courts of a number of countries for decision. By most of them the French legislation was upheld even as regards local ${ }^{7}$ indorsers. A contrary conclusion was reached by the Supreme Commercial Court of Leipsic ${ }^{8}$ and by the Commercial Court of Zurich. ${ }^{8}$ A considerable literature on the subject arose at that time both in decisions and in juristic opinion; a summary of this according to countries will be found in Appendix B, infra.

A review of the decisions and the juristic opinion on the recognition of moratory legislation enacted by a foreign state shows that no agreement was reached with respect to the French moratory legislation of I870-187I. Although most of the decisions and text-writers sustained the legislation even as regards local indorsers, there was the greatest variety of opinion concerning the basis upon which such recognition should rest. The emphasis placed by most of the courts upon the fact that the French legislation merely extended the time for protesting, and prohibited any action on the instrument until the expiration of the moratory period, raises the question whether the courts which recognized that legislation as valid would reach the same conclusion as regards the legislation of the present war which extends the maturity of bills and notes. The great majority of jurists have expressed the opinion that a postponement of maturity by the law of the place where the bill or note is payable cannot be recognized with respect to local drawers and indorsers. ${ }^{10}$ Inasmuch as most of

\footnotetext{
"The term "local" indorser in this article refers to a person who indorsed the instrument in the state or country in which the suit arises.

${ }^{8}$ Decision of Feb. 2I, 187I, I R O H G, 286; I Clunet, 185; Dalloz, r872, p. $48 \mathrm{r}$, note. An abstract of the case may be found in 18 Goldschmidts Zeitschrift, 628.

'Decree of May 22, 187x, 22 Zeitschrift für Kunde und Fortbildung der zürcherischen Rechtspflege, 37x. A summary of the case may be found in 17 Goldschmidt's Zeitschrift, 3or.

${ }^{20}$ Audinet, Principes élémentaires de droit international privé (2d ed.), 6r4; Bar, Private international law, 683; Bernstein, Allgemeine deutsche und allgemeine österreichische Wechselordnung, 360; Despagnet, Précis de droit international privé (5th ed. by de Boeck), 997; Fick, Ueber internationales Wechselrecht in Beziehung auf Fristbestimmungen, insbesondere die französischen Wechsel-Moratoriums-Gesetze und Dekrete, pp. 67-70; Goldschmidt, System des Handelsrechts (4th ed.) 268; 2 Grünhut, Wechselrecht, 584, n. 52; Hovy, M. A. J., Jets over de gevolgen der Fransche wet van 13 Augustus 1870 met
} 
the current legislation has taken this form, instead of merely postponing the time for protesting, it is of the utmost importance to determine whether any distinction based upon the form in which the legislation is expressed should properly be drawn between the various kinds of moratory legislation. So far as the countries considered in this article are concerned, the moratory legislation passed shows in this respect the following varieties:

(I) Legislation extending the time for protesting (Belgium);

(2) Legislation granting days of grace (Switzerland) ;

(3) Legislation extending the time for payment (Austria);

(4) Legislation postponing the maturity (England, France, Germany, Italy).

An attempt will be made in the following pages to show that moratory legislation enacted by the law of the place where a bill or note is payable can and should be recognized without reference to the form in which it is expressed, as regards all parties to the instrument, including local drawers and indorsers.

\section{VALIDITY OF MORATORY LEGISLATION AS BETWEEN THE HOLDER} AND THE MAKER OR ACCEPTOR

Let us assume that $X$ is the holder of a note which was executed by $A$ in New York on May ro, 1914, and was payable in Paris three months after date. By a decree of the French Government of July 3I, I9I4, the time for protesting and for all other acts required for the preservation of recourse of negotiable instruments issued before August I, r9I4, and falling due between August I and I5, was extended thirty days. By subsequent decrees the maturity of these instruments was further extended. Let us assume that demand for payment was made on August ro and that payment was refused. Can suit be brought against $A$ in the United States before the expiration of the time for payment granted by the French moratory legislation?

Suppose in the next place that $X$ is the holder of a bill that was drawn in New York on May Io, I9I4, upon $A$ in Paris, payable in Paris three months after date, and that $A$ accepted the bill. Demand

betrekking tot de wisselverbindtenissen buiten Frankrijk aangegaan. Magazijn van handelsregt, 1870. Mengelinen, 48; Jacques, H., Die durch die französischen Moratorienverfügungen hervorgerufenen Regressfragen. Allgemeine österreichische Gerichtszeitung, 1871, 40I; Keysser, I7 Goldschmidt's Zeitschrift für das gesamte Handelsrecht, 298; Kist, 18 Goldschmidts Zeitschrift, 643; Lehmann, Lehrbuch des Wechselirechts, 132; 4 Lyon-Caen \& Renault, Traité de droit commercial (4th ed.), no. 663; Norsa, Monitore dei tribunali, 418; Ottolenghi, La cambiale nel diritto internazionale, 435; Staub, Kommentar zur deutschen Wechselordnung, art. 86, n. 9; Surville \& Arthuys, Cours ellementaire de droit international prive (6th ed.), 736 . 
for payment was made on August Io and payment refused. Can suit be brought against $A$ in the United States before the expiration of the time for payment granted by the French moratory legislation?

The answer will depend of course upon the question whether the French legislation is binding upon $A$ and $X$. If we assume that the question is brought before the courts of New York the problem will have to be solved in accordance with the rules of the conflict of laws governing in that state. The fact that the note was payable in Paris and that the bill was accepted in Paris makes each case a pluri-territorial one which must be resolved by the New York rules relating to the conflict of laws. Let us assume that upon consulting those rules the New York judge will find that the contractual obligation between $A$ and $X$ is to be determined by the law of the place of performance, ${ }^{11}$ that is, French law. It is clear, then, that the law of New York has incorporated French legislation as an operative fact. ${ }^{12}$ Let us assume also for the sake of simplifying the problem that it

\footnotetext{
${ }^{11 B r a b s t o n}$ v. Gibson (1850, U. S.) 9 How. 263, I3 L. Ed. I3I; Mason v. Dousay (1864) 35 Ill. 424; Smith v. Blatchford (1850) 2 Ind. I84, 52 Am. Dec. 504; Hunt v. Standart (1860) I5 Ind. 33, 77 Am. Dec. 79; Rose v. Park Bank (1863) 20 Ind. 94, 83 Am. Dec. 306; Emanuel v. White (I857) 34 Miss. 56, 69 Am. Dec. 385 ;. Strawberry Point Bank v. Lee (I898) II7 Mich. I22, 75 N. W. 444; Barger v. Farnham (I902) I30 Mfich. 487, 90 N. W. 28I; Freeman's Bank v. Ruckman (I860, Va.) I6 Gratt. I26; Emerson v. Patridge (I854) 27 Vt. 8, 62 Am. Dec. 6r7.

The New York law is uncertain. The recent tendency of the courts has been to apply the law of the place of contracting. Stumpf $v$. Callahan (1905) Ior App. Div. 383; McClement v. Supreme Court, Independent Order of Foresters (I914) 88 Misc. 475. Formerly the prevailing view favored the law of the place of performance. Curtis v. Del. L. \& W.R. (1878) 74 N. Y. II6; Williams v. Central $R$. $R$. (1905) 183 N. Y. 518, aff'g. 93 App. Div. 582.

The German courts agree with the prevailing view in this country. Decision of the Supreme Court of Jan. 17, I882, 6 R G, 24.

The French law assumes in the absence of an express declaration of intention that the parties contracted with reference to the law of the place of making. Cass. Feb. 6, I900, S. I900, I, I6I and note.

In Italy the intention of the parties controls. If they have the same nationality they will be deemed to have contracted with reference to such law. In the absence of a common nationality they will be deemed to have intended the law of the place of contracting. Art. 58, Commercial Code.

The English law is uncertain. Art. 72 (2) of the English Bills of Exchange Act states that the law of the place where the contract is entered into shall govern its "interpretation." The term "interpretation" will be held no doubt to include the obligation of the contract. But it seems that the English act intended to follow Story's view, which supports the law of the place of payment when there is a disagreement between the law of the place of making and the law of the place of performance. See Chalmers, Bills of Exchange (6th ed.) 244; Dicey, Conflict of Laws (2d ed.) 593-594. Subdiv. 3 of Art. 72 expressly provides that the necessity for protest or notice of dishonor shall be determined by the law of the place where the bill is dishonored.

${ }^{12}$ See (Igr8) 28 Yale Law Journal, 67.
} 
incorporates the French local legislation only, to the exclusion of the French rules of the conflict of laws. ${ }^{13}$

The specific problem presented by the facts of our cases is whether the New York law (lex fori) should incorporate the French moratory decrees, which modified the original contractual obligation as regards time of payment. That it should do so in the light of the established practice in this country is apparent. Whatever difference of opinion there may be in general as regards the law governing the subsequent modification of a contractual obligation, ${ }^{14}$ no difficulty arises under the facts of this case. Any court adopting the law of the place of performance rather than the law of the place of contracting as the law determining the obligation of contracts would in the nature of things apply the same rule, subject to the rules of public policy of the forum, to any subsequent modification of the contractual obligation resulting from moratory decrees changing the time for payment.

The French decrees were made in accordance with the authority which had been conferred upon the government by the laws of January 27 and December 24, I9Io. ${ }^{15}$ As these laws existed at the inception of $A$ 's contract, it might be contended that the contract was subject to the liability of being modified in this manner. Suppose, however, that the note had been payable in Brussels and that the bill was drawn on and had been accepted by $A$ in Brussels. In Belgium the government had no general authority to extend the time for the payment of bills and notes. For this reason the royal decree of August 2, I9I4, which granted the first moratorium in Belgium, was confirmed by the law of August 4. Would the fact that the modification of the original contractual obligation was caused by retroactive legislation change the above result? The answer is clearly "no." Whether the change in the contract extending the time for payment is made by an executive decree or through retroactive legislation can be of no consequence so long as such decree or law was authorized at the inception of $A$ 's contract. ${ }^{16}$ As there is no constitutional provision in England or in any of the continental countries prohibiting retrospective legislation it is manifest that the result should be the same.

The New York judge may be confronted with the argument, however, that the recognition of the French moratory legislation would impair the obligation of the contract existing between $A$ and $X$ and

${ }^{13}$ If it incorporates the French law in its entirety including its rules of the conflict of laws the problem of renvoi is presented which has been discussed by the writer elsewhere. See The Renvoi Theory and the Application of Foreign Law (19io) to Columbia L. Rev. 327, 344; The Renvoi Doctrine in the Conflict of Laws-Meaning of "The Law of a Country" (I9I8) 27 YALE IAW JoURNaL, 509 .

${ }^{14}$ See the discussion of this point in (IgI7) 26 YALE LAW JouRNAL, 773-774.

${ }^{15}$. Duvergier, Collection complète des lois, decrets, etc. IgI4, pp. 93, 698 .

${ }^{16}$ (IgI7) 26 YALE LAW Journal, 775. 
should not be recognized on that ground. The contention might take the following form: Under the federal Constitution, which prohibits states from passing laws impairing the obligation of contracts, the state of New York cannot pass moratory legislation postponing the time for the payment of bills and notes. It is against the policy of the state therefore to enforce foreign legislation of a similar nature. If the suit were brought in a state in which there is a constitutional prohibition against the passing of retrospective legislation it might be argued that the French legislation could not be recognized or enforced in the face of such a prohibition. It is apparent, however, that neither the impairment clause of the federal Constitution nor the provisions of the state constitutions prohibiting retrospective legislation have any application to our case. These provisions are restrictions upon the legislative power of the states of this Union. They do not prohibit the recognition of such legislation validly enacted by foreign states.

Neither can the above provisions be regarded as an indication of a public policy of the forum which forbids under all circumstances the recognition or enforcement of such foreign legislation. The following words from a note in this JourNal with reference to the subject in hand may be quoted in this connection :17

"The resultant legal relation is, after modification no less than before, in all respects consistent with the public policy of the forum. Nor is the fact of modification itself repugnant to that policy. In this respect the result is not unlike that of a contract expressly conditioning a modification of its terms upon a subsequent fact beyond the control of the parties. To proceed, in such a case, merely upon a disapproval of a foreign constitutional policy, irrespective of the unobjectionable nature of the resultant situation, would be to give weight to a matter with which the forum could have but little concern, much as if it were to refuse to recognize a title to property acquired in a foreign state, because of the objectionable character of the law under which that title was acquired. In neither case would the law of the forum be acting with a view to preserving vested rights, but merely creating rights of its own unlike those vested under the law of the place."

Not only is there no policy in the state of New York opposed to the recognition of foreign moratory legislation, but such recognition is positively demanded by the strongest economic and political reasons. These will be considered below.

In view of the above it is submitted that Professor Fick's ${ }^{18}$ contention that moratory legislation enacted at the place where the bill or note is payable should be recognized only so far as it exists at the

${ }^{17}$ Ibid. $775-776$.

${ }^{13}$ Fick, 53 et seq. 
inception of the particular contract is unsound. And on this point there would appear to be general agreement.

Should the forum determine the obligation of contracts in accordance with the law of the place of contracting instead of the law of the place of performance, the problem would assume a different form so far as the maker of the note is concerned. The question would then be upon what theory the obligation of the contract which was entered into in New York can be modified by the moratory legislation of a foreign country. If the law creating the obligation necessarily controls also any subsequent modification of the contractual obligation, the New York courts would, of course, be unable to recognize the French decrees. There is authority, however, for the proposition that everything relating to the performance of a contract is subject to the law of the place of performance. On that ground the moratory legislation of the place of payment might be supported. Mr. Justice Hunt, in Scudder v. Union National Bank of Chicago, laid down the following rules: ${ }^{19}$

"Matters bearing upon the execution, the interpretation, and the validity of ' a contract are determined by the law of the place where the contract is made. Matters connected with its performance are regulated by the law prevailing at the place of performance."

The Court of Appeals of New York has recognized the same distinction more recently in the case of Union National Bank v. Chapman. The learned court, speaking through Mr. Justice Haight, says : ${ }^{20}$

"I. All matters bearing upon the execution, the interpretation and the validity of contracts, including the capacity of the parties to contract, are determined by the law of the place where the contract is made. 2. All matters connected with its performance, including presentation, notice, demand, etc., are regulated by the law of the place where the contract, by its terms, is to be performed."

Moratory legislation of the place of payment might be supported on the ground that it falls within the second of the above rules. So far as this kind of legislation is concerned it would seem sound policy to hold that the country in which the bill or note is payable should be able to control the payment of the instrument so long as it acts reasonably in accordance with the necessities of the situation.

\section{VALIDITY OF MORATORY LEGISLATION AS BETWEEN THE HOLDER} AND THE DRAWER OR INDORSER

The real controversy relating to the recognition of foreign moratory legislation has had reference to the local drawer and indorser. Let

"(1875) .9I U. S. 406.

${ }^{20}$ (1902) I69 N. Y. 538, 543 . 
us assume again that a bill is drawn on May 1o, 1914, in New York on $A$ in Paris (London, Brussels, Rome, etc.) payable three months after date, and that $B$ indorsed the bill in New York. Let us suppose also that $X$, the holder, does not present the instrument for payment until after the expiration of the foreign moratory period. If proper demand is made upon $A$ when the period expires and $A$ fails to pay, can $X$ hold $B$ in New York upon proof of the foreign moratory legislation and of the demand, protest and notice?

If the courts of New York should look upon B's contract as a contract to be performed in Paris (London, Brussels, Rome, etc.) the problem would be the same as the one already discussed. The obligation of $B$ 's contract would be governed by the local French (English, Belgian, etc.) law and the French (English, Belgian, etc.) law incorporated by New York law would include its moratory legislation, although it was passed subsequent to the inception of $B$ 's contract. This view of the contract of the drawer and indorser appears to be taken by the English courts. It was so held expressly in the case of Rothchild $v$. Currie ${ }^{21}$ and the decision on this point was approved in Hirschfield $v$. Smith. ${ }^{22}$ The same view was taken also in the two English cases that have recognized the French legislation of I870$187{ }^{23} .^{23}$

But by the overwhelming weight of American authority, $B$ has obligated himself to pay the instrument after due presentment, protest and notice, not in Paris, London, etc., but in New York. ${ }^{24}$ So far

${ }^{21}$ (I84I) I Q. B. 143, 10 L. J. Q. B. 77.

$=$ (1866) I C. P. 340,35 L. J. C. P. I77. But see Allen v. Kemble (1848) 7 Moore P. C. 314 See also Dicey, Conflict, of Lawes (2d ed.) 596-597; Foote, Private International Jurisprudence (4th ed.) 4II; Westlake, Private International Law (5th ed.) 3 rg.

${ }^{23}$ Rouquette v. Overmann (1875) L. R. 10 Q. B. 525, 44 L. J. Q. B. 22I; Allatini \& Co. v. Abbott (1872) 26 L. T. Rep. (N. S.) 746.

${ }^{24}$ Crawford v. Bank (1844) 6 Ala. 12, 4I Am. Dec. 33; Hunt v. Standart (1860) 15 Ind. 33, 77 Am. Dec. 79; National Bank v. Green (I87I) 33 Ia. 140; Short v. Trabue (1868) 4 Met. (Ky.) 299; Wood v. Gibbs (1858) 35 Miss. 559; Price v. Page (1856) 24 Mo. 65; Briggs v. Latham (1887) 36 Kan. 255, 59 Am. Rep. 546; Kuenzi v. Elvers (I859) I4 La. Ann. 39I, 74 Am. Dec. 434; Freese v. Brownell (187I) 35 N. J. L. 285, Io Am. Rep. 239; Mackintosh v. Gibbs (I9II) 8r N. J. L. 577, 80 Atl. 554, Ann. Cas. I912 D I63; Trabue v. Short (1866) I8 La. Ann. 257; Powers v. Lynch (1807) 3 Mass. 77; Williams v. Wade (1840, Mass.) I Met. 82; Aymar v. Sheldon (1834) I2 Wend. 439, 27 Am. Dec. I37; Spies v. National City Bank (1903) I74 N. Y. 222; 66 N. E. 736, 61 L. R. A. 193; Amsinck v. Rogers (Ig07) 189 N. Y. 252, 82 N. E. I34, 12r Am. St. Rep. 858, I2 L. R. A. (N. S.) 875; Lennig v. Ralston (1854) $23 \mathrm{~Pa}$. St. 137; Read v. Adams (182I) 6 Serg. \& R. (Pa.) 356; Douglas v. Bank of Commerce (1896) 97 Tenn. I33, 36 S. W. 874; Warren v. Citizens Bank (1894) 6 S. D. I52, 60 N. W. 746; Raymond v. Holmes (1853) II Tex. 54.

A few cases take a contrary view. Dunn v. Welsh (I879) 62 Ga. 24I; Hibernian National Bank v. Lacombe (I88I) 84 N. Y. 367; Peck v. Mayo (I842) I4 Vt. 33, 39 Am. Dec. 205. 
as the drawer or indorser is concerned it is apparent therefore that the English cases on the subject can have little weight in this country. Most of the continental courts and writers, ${ }^{25}$ on the other hand, agree with the American courts in their view of the nature of the contract of the drawer and indorser. Although many of them would determine the obligation of a contract in accordance with the law of the place of contracting rather than with the law of the place of performance, this difference in the law is of no consequence so far as the contract of the drawer and indorser is concerned. The lex loci contractus and the lex loci solutionis here coincide. The continental decisions and juristic discussions are therefore directly pertinent.

The question thus presented is: Assuming that New York follows the majority view with regard to the nature of the contract of the drawer and indorser, upon what line of reasoning can the French moratory legislation be sustained with respect to $B$, the New York indorser? The obligation of $B$ 's contract being controlled in general by the law of New York, how can the moratory legislation enacted at the place of payment of the bill be binding upon him?

All courts holding that the contracts of the drawer and indorser are independent contracts governed by the law of the place where they are respectively entered into find it necessary to make exceptions to that rule. In some respects the law of the place where the instrument is to be presented for payment is incorporated with regard to all parties to the instrument. It would be highly inconvenient, for example, if the mode in which presentment for acceptance or payment or protest must be made were to be subject to the law governing the contract of each party to the instrument. Hence it is universally admitted that everything concerning the "form" or "mode" of presentment and protest is determined by the law of the place where such acts must be done. If the law of that place is satisfied the act will be recognized everywhere.

By universal assent the same rule is also applicable to the time within which such presentment and protest may be made. ${ }^{28}$ The law of the

\footnotetext{
${ }^{25}$ Asser \& Rivier, Eléments de droit international privé, 210; Audinet, 620; Beauchet, Amnales de droit commercial, I888, II, $63 ; 3$ Diena, Trattato di diritto commerciale internazionale, 209; Fiore, Elementi di diritto internazionale privato, 459; Ottolenghi, 472; Surville \& Arthuys, 690; Staub, art. 86, sec. 8. Contra: Decision of a court of Geneva of March 25, I872, Journal de Geriève, Apr. Io, I872, n. 84; Sirey, 1872, 2, 217, Belgique judiciaire, I872, col. 524; Annali, I, 47, note. An abstract of the case may be found in 21 Goldschmidt's Zeitschrift, $58 \mathrm{r}$.

${ }^{20}$ Pierce v. Indseth (I883) I06 U. S. 546; Carter v. Union Bank (I847, Tenn.) 7 Humph. 548; Commercial Bank of $K y$. v. Barksdale (1865) 36 Mo. 563 ; Sylvester v. Crohan (1893) I38 N. Y. 494, 34 N. E. 273; Douglas v. Bank of Commerce (1896) 99 Tenn. 173, 36 S. W. 874.

See also Bar, Private International Law, 674; 3 Diena, 147; Champcommunal, Annales de droit commercial, 1894, II, 204; Esperson, Diritto cambiario inter-
} 
place of payment determines the hours of the day within which such acts may be done, and where the day of maturity falls on a Sunday or holiday, that law determines whether the presentment and protest must be made on the following or on the preceding business day.

Days of grace have now been generally abolished, but they still exist in England. The existence of such grace and the determination of the time of presentment and protest where grace exists are likewise held everywhere to be subject to the law of the place of payment. ${ }^{27}$

May the above rules not be invoked by way of analogy to support moratory legislation enacted by the law of the place where the instrument is payable?

I. View sustaining moratory legislation so far as it extends time for protesting.

The Supreme Court of Austria ${ }^{28}$ and a number of authors ${ }^{29}$ would recognize moratory legislation enacted by the law where the bill is payable (France, England, etc.) with respect to local drawers and indorsers if the legislation merely extends the time within which the protest is to be made. Their reasoning is as follows: The rule that the "form" of the acts necessary to the preservation of the right of recourse must be according to the lex loci actus includes also the "time" within which protest must be made, because the timeliness of the protest belongs to the formalities which must be observed for the preservation of such right of recourse. It is evident, however, that such an argument confuses form and substance. Where the holder is granted a few days after presentment for the drawing up of the protest, the matter is properly spoken of as "form," which should be controlled by the law of the place where the act is to be done. In countries where the dishonor of all instruments domestic or foreign must be proved by formal protest and where the "noting" of the

nazionale, 90; 2 Grünhut, Wechselrecht, 585; 4 Lyon-Caen \& Renault, 563; Ottolenghi, 268; Surville \& Arthuys, 729. But see Musson v. Lake (1846, U. S.) 4 How. 262.

${ }^{27}$ Washington Bank v. Triplett (I828, U. S.) I Pet. 25; Skelton v. Dustin (1879) 92 I11. 49 ; Brown v. Jones (1890) I25 Ind. 375, 25 N. E. 452 ; Thorp v. Craig (1860) Io Iowa, 46r; Bowen v. Newell (1855) I3 N. Y. 290; Blodgett v. Durgin (I859) 32 Vt. 36I; Second National Bank v. Smith (I903) II8 Wis. I8, 94 N. W. 664 .

See also Audinet, 614; Bar, 674; Chrétien, Etude sur la lettre de change en droit international privé, 188I, p. I48; Despagnet, 994; Esperson, 90; 3 Diena, I50; 2 Grünhut, 585; 4 Lyon-Caen \& Renault, 563; 2 Rolin, Principes du droit international privé, no. 963; Surville \& Arthuys, 680-68I ; Ottolenghi, 290-29r; 4 Weiss, 465 .

${ }^{28}$ Decisions of May 28, I872, Krall, nos. 214, 215; Decision of June I3, I872, Krall, no. 216. Concerning these cases see Appendix A.

${ }^{20}$ Despagnet, no. 346; Fick, 39-40; 2 Grünhut, 584, n. 52; Lyon-Caen \& Renault, Belgique judiciaire, 1873, co1. 569; Swoboda, Allgemeine österreichische Gerichtszeitung, 30I; Vidari, 7 Archivo giuridico, 267; 9 Archivo giuridico, I88; 4 Weiss, p. 466 , note. 
Anglo-American law is unknown, it is under certain conditions unreasonable to ask that such instrument is to be protested on the day of maturity. In certain places, for example Paris, ${ }^{30}$ a large number of bills of exchange become payable at certain banks at the same time and it would be a physical impossibility to have all protests drawn up on the same day. Because of such conditions an allowance of one or two days is often made for drawing up the protest. ${ }^{31}$ The rule invoked in support of the recognition of foreign moratory legislation has in view this situation particularly. It supports clearly those provisions of the French moratory legislation of I870-I87I and those of the present war which extend the time ordinarily granted for drawing up the protest. The fact that many of the notaries may be in the army or may be otherwise engaged in the service of their country naturally makes such legislation both necessary and reasonable. Whether the time reasonably necessary under the conditions existing in a given country for the drawing up of the protest be two days or ten days, the delay caused thereby is relatively speaking of such little importance that it cannot seriously affect the interests of the different parties.

The rule does not go beyond the above cases, however, and does not support moratory legislation whose very object it is to give time to the debtor to pay. Although the greatest pains may be taken by the legislature so to phrase the legislation that only the time for protesting is postponed, if as a matter of fact payment cannot be demanded or enforced during the time of such extension-as it could not be under the French legislation of $1870-187 \mathrm{I}$ and cannot be under the Belgian legislation of the present war, -the matter concerns no longer the time for drawing up the protest, but the time when payment can be legally demanded and enforced.

It is apparent, in view of the fact that the real object of moratory legislation is to give time to the debtor, that such legislation of the place of payment cannot be respected in the United States, as regards American drawers and indorsers, by virtue of the rule which submits the "time for protesting" to the law of the place of payment, so far as it relates to "formalities."

Attention may be called to the fact that so far as the present war legislation is concerned the theory here rejected would sustain only the Belgian legislation and not the legislation of the other countries considered in this article.

${ }^{30}$ See Proceedings of the Conference of the Hague of I9I2, Sen. Doc. I62, $63 \mathrm{~d}$ Cong. Ist sess. 290.

${ }^{21}$ Under the Uniform Law of the Hague Convention relating to bills and notes, of 1912, protest must be made either on the day when the bill or note is payable or on one of the two succeeding business days. Art. 43, par. 2, Uniform Law. 
2. View sustaining moratory legislation as extraordinary days of grace.

A second line of reasoning upon which it has been attempted to justify the recognition of moratory legislation enacted at the place of payment (France, England, etc.) with respect to local drawers and indorsers is based upon the analogy of the rule governing days of grace. ${ }^{32}$ The argument admits the correctness of the conclusion stated above but submits that, inasmuch as days of grace are controlled by the law of the place of payment with respect to all parties, moratory legislation conferring extraordinary days of grace should be respected likewise. In order to test this argument let us assume that the moratory legislation expressly states, as does the Swiss decree of August 3, I9I4, that the extension is granted as days of grace. Would this fact be sufficient to secure recognition for such legislation everywhere?

That the question of days of grace is controlled by the law of the place of payment with respect to all parties is universally conceded to-day. Originally such days constituted a period of grace which the holder might grant to the debtor after maturity. In the course of time the original meaning and significance of days of grace were changed, however. Daniel ${ }^{33}$ makes the following observations on the subject:

"They were originally days allowed by way of favor to the drawee of a foreign bill to enable him to provide funds for its payment without inconvenience; and were called 'days of grace,' or 'respite days,' because they were gratuitous, and dependent on the holder's pleasure, and not to be claimed as a right by the person on whom it was incumbent to pay the bill. By custom, however, they became universally recognized; and, although still termed 'days of grace,' they are now considered wherever the law merchant prevails as entering into the constitution of every bill of exchange and negotiable note, both in England and the United States, and form so completely a part of it that the instrument is not due in fact or in law until the last day of grace."

At a time when days of grace were in fact a slight concession which the law of the place of payment allowed the holder to make to the debtor for the purpose of protecting his credit and preventing his being thrown possibly into bankruptcy, it was natural that all countries should recognize such days of grace as an "incident of payment." Just as the law of the place of payment might grant to the holder a few days within which presentment or protest might be made it was recognized that it might extend a similar indulgence to the

${ }^{32}$ Ladenburg, 7 Centralorgan für das Handels- und Wechselrecht (N. S.) 288, 290-292; Lebano, I8 Goldschmidt's Zeitschrift, 629; Van Raalte, I7 Goldschmidt's Zeitschrift, 306.

Daniel, Negotiable Instruments (6th ed.) sec. 614. 
debtor. Such legislation might be regarded as affecting only incidentally the obligation of the parties and as relating therefore to the "formalities" or "incidents" of payment rather than to the substance of the obligation.

Should a different rule prevail to-day when the original character of days of grace has been lost, so that in countries in which they still exist they postpone the maturity of the instrument by the number of days granted? The courts as well as the jurists have generally held that days of grace existing at the place of payment are also binding upon the local drawer and indorser. ${ }^{34}$ They appear to have so held largely because it had become the traditional rule. The fact that the original character of the so-called days of grace had been changed was not observed or if it was observed it did not affect the result. Most of the writers regard days of grace as not affecting the maturity of the instrument but only the precise day of payment or the incidents of payment. ${ }^{35}$ Yet on strict theory it might be argued from the standpoint of the conflict of laws that the law of the place of payment should not determine the question of grace to-day unless such law should be deemed to control, with respect to all parties, the time of payment in general.

Be that as it may, inasmuch as the existence of ordinary days of grace is governed under the positive law of all countries by the law of the place where the instrument is payable, may not the same rule be invoked with respect to moratory legislation of such place which grants a somewhat longer period of grace to the debtor? If the moratory legislation in question should grant to the debtor only a brief period within which to pay, let us say a week or possibly two weeks, it would be difficult to contend that the rule governing days of grace did not apply. But is it possible to maintain that the same rule should govern if the legislation postpones for eleven months the time for presentment, as did the French moratory legislation of I870-1871, or even for a number of years as may be the case under the moratory legislation enacted during the present war? The contention has been made that as days of grace are controlled in the conflict of laws by the law of the place of payment, such law governs absolutely, and that the number of days or months granted is of no importance. $^{36}$ This contention fails, however, to keep in mind two fundamental facts. One is the cardinal rule in the conflict of laws

\footnotetext{
"It is generally admitted that such days of grace will be recognized, although they were introduced by the law of the place of payment subsequent to the inception of the defendant's contract. Bar, 683, note; Chrétien, I92; 4 LyonCaen \& Renault, 568.

${ }^{25}$ See, for example, 2 Grünhut, 585; Ottolenghi, 290.

*Van Raalte, I7 Goldschmidt's Zeitschrift, 306.
} 
that the recognition of the law of a foreign state can have operation only so far as the law of the forum on grounds of justice, convenience and policy may give it effect. If the law of the forum has seen fit to recognize ordinary days of grace granted by a foreign state it must have done so because, after a consideration of the advantages to the enacting state of such a rule and its disadvantages to the interests of the forum, the balance of convenience was deemed to be in favor of the recognition of such foreign law. It does not follow of necessity that the same conclusion will be reached with respect to foreign moratory legislation.

The above contention disregards in the second place the fact that the difference between one legal rule and another is often merely a matter of degree. The rule that the "formalities" or "incidents of payment" are subject to the law of the place where the act is to be done or payment is to be made may serve a useful object. It may not be objectionable as a mere form of expression to hold that a few days granted to the holder within which he may protest or present the instrument and a few days of grace granted to the holder shall be deemed such formalities or incidents. Even if the contract of the local drawer or indorser is regarded as subject to the law of the place where it is both made and to be executed-the general view in this country,-it may be a convenient rule that all questions affecting payment or the mode in which certain acts must be done should be allowed to be carried on internationally in accordance with the law of the place where such act is to take place. Each state is interested in having its own usages in this regard observed by other nations and for that reason it must be willing to recognize the usages of other countries. Where a few days of grace are added by the law of the place of payment the hardship on the drawer and on the indorser may be regarded as so trifling that such legislation should be recognized, in view of the fact that all countries formerly allowed days of grace. To-day when days of grace have lost their original character and have no longer any proper function to perform and have therefore been generally abolished, the rule that the law of the place of payment should govern in this regard may be said to rest largely upon tradition, unless indeed it can be supported on the ground that the time of payment is controlled by the law of the place of payment. Under these circumstances the application of the rule to moratory legislation granting the debtor a considerable period of time within which to pay cannot be justified. Bar is quite right when he says in this connection that "it is merely playing with words to say that days of grace may just as well last for seven or eleven months as for two to ten days."37

${ }^{2 \pi}$ Bar, 683. To the same effect, 4 Lyon-Caen \& Renault, no. 662; Ottolenghi, 434. 
3. Prospective moratory legislation sustained by virtue of rule goverining maturity.

In some of the countries other than the Anglo-American a bill of exchange may be drawn payable at a public fair or at usance. If it is drawn payable at a fair, which may last for several days or longer, the precise day of payment must of necessity be fixed by legislation or by custom. In most countries it is provided now that the bill shall be payable on the day before the closing of the fair. ${ }^{38}$ In Spain ${ }^{30}$ it is payable on the last day. If a bill is drawn in Spain on a fair in France, will the Spanish or the French law determine when the bill is due? The only rule that is practicable is clearly the law of the place where the instrument is payable. This is conceded also by most of the writers. ${ }^{40}$

Formerly, instruments were frequently payable at usance. According to the law of some of the continental countries, the time of payment in a bill may still be fixed in this manner. As the name indicates, these instruments originally became due after a period fixed by usage, a period which corresponded more or less to the time it would require a letter to pass from the place of issue to the place of payment. To-day such rules are fixed by the codes of the different countries in which such bills are still recognized. If the law of the place of issue fixes such period differently from that of the place of payment, which law will determine the maturity of the instrument? Here again it is generally held that the law of the place of payment should control.41

The maturity of a bill may depend also upon a difference in calendars. Suppose a bill of exchange is drawn in this country on Petrograd and is payable on July Ist. Will the instrument be due on July Ist according to our calendar or on July Ist according to the Russian calendar? The English Bills of Exchange Act would determine maturity in accordance with the Russian calendar. ${ }^{42}$

\footnotetext{
${ }^{28}$ France, art. I33, Commercial Code; Germany, art. 35, Bills of Exchange Act; Italy, art. 286, Commercial Code.

${ }^{2}$ Art. 452, Commercial Code.

3 Diena, I48-149; Hartmann, Das deutsche Wechselrecht, 216.

In favor of the law of the place of issue, Champcommunal, Annales, 1894, II, 203. Most authors hold that a postponement of the fair also operates as a postponement of the maturity of the instrument. Supino, Della cambiale $e$ dell' assegno bancario, 185; 2 Treitschke, Encyclopädie des Wechselrechts, 567-68I; Swoboda, Allgemeine österreichische Gerichtszeitung, I87I, no. 75, p. 298; Wächter, Das Wechselrecht des deutschen Reichs, 323. Contra: 5 Cesarini, Principii del diritto commerciale, ch. 24, no. 7, p. 7; Vidari, La lettera di cambio, no. 358 .

a Blaschke, Oesterreichisches Wechselrecht, 26-27; Lehmann, Wechselrecht, 37I; 3 Diena, I48-149. Contra and in favor of the lex loci contractus: Hartmann, Das deutsche Wechselrecht, 160.

"Bills of Exchange Act, art. 7 (5).
} 
Article 34 of the German Bills of Exchange law provides as follows:

"If a bill, payable after date within the empire (Inland), be drawn in a country reckoning by the old style, and there be no statement thereon that the bill is dated after the new style, or, if such bill be dated according to both styles, the date of maturity is to be reckoned according to the day of the calendar of the new style which corresponds with the day of drawing according to the old style."

The article applies the calendar of the place of issue but it affects only bills drawn on Germany from a country having the old style of calendar which are payable after date. If a bill drawn in Russia on Germany is payable on a particular day German law applies. Even where a bill is payable after date and is drawn in Germany on a country having the old style, the rule contained in article 34 is not applied by way of analogy and the date of maturity is determined in accordance with the calendar at the place of payment. ${ }^{43}$ Elsewhere the law is uncertain. The writers are divided between the law of the place of issue ${ }^{44}$ and that of the place of payment.45 The Convention of the Hague of $1912^{46}$ relating to bills and notes has adopted the rule of the place of payment as governing in the matter of calendars, and this seems to be the practice of the bankers. ${ }^{47}$ And this view-that the place of payment controls-is the true one. Where the drawer has not taken the precaution of expressing himself unequivocally by inserting the date of maturity according to both calendars, he has no just ground of complaint if the instrument is interpreted in the way it would be understood at the place of payment.

If we also take into consideration the cases holding that maturity, so far as it depends upon days of grace, is controlled by the law of the place where the instrument is payable, the generalization may be warranted that the maturity of bills and notes is determined by the law of the place where they are payable. Article 7, subdivision 5, of the English Bills of Exchange Act has the express provision that the due date is to be governed by this law. The American cases lead to the same conclusion. Where this rule is established it must govern with respect to all parties, for it is manifestly impracticable to have different dates of maturity with respect to the different parties to such instruments.

If the due date of a bill or note is determined in accordance with the law of the place where the instrument is payable the rule will

${ }^{4}$ Staub, Wechselordnung (ed. by Stranz) art. 34, nos. 4, 5.

"Audinet, 6I4; Champcommunal, Ammales, I894, II, 20r; Chrétien; 142; Despagnet, 994; 2 Jitta, La substance des obligations, 8I, III; Surville \& Arthuys, 725.

45 Bar, 675; Esperson, 89; 2 Grünhut, 585; 4 Lyon-Caen \& Renault, 563; 4 Weiss, 465-466. Compare 3 Diena, I44-I46; Ottolenghi, 265-266.

${ }^{45}$ Art. 36, Uniform Law.

"Where the day of payment is a certain time after date the actual date must of course be understood. Bar, 675 . 
likewise apply to the moratory legislation of that place, so far as it operates prospectively, postponing the day of maturity or time for payment. The law of the place of payment naturally includes the moratory legislation there passed as well as the other rules there in force.

We have thus found a rule upon which the recognition of moratory legislation enacted at the place where the instrument is payable, and existing at the time the instrument was issued, may be based, irrespective of the form in which such legislation may be expressed and irrespective of the rule of the conflict of laws which may be established at the forum concerning the law governing the obligation of contracts in general. This rule does not go far enough, however. In order to be effective moratory legislation must be given retroactive effect. The question remaining to be determined is, therefore: How can retrospective moratory legislation of the place of payment be supported with respect to American drawers and indorsers? A theory must be found which will sustain such legislation with respect to American drawers and indorsers not only without reference to the form in which it is expressed but also without regard to its prospective or retrospective operation.

4. Grounds upon which retrospective moratory legislation has been sought to be sustained.

(a) English decisions.

The French moratory legislation of I870-I87I was recognized in England by the Court of Queen's Bench in the case of Rouquette $v$. Overmann ${ }^{48}$ and by the English Supreme Consular Court at Constantinople in the case of Allatini \& Co.v. Abbott. ${ }^{49}$ The former relied for its decision upon three grounds. The first argument was that the question affected the "incidents of presentment and payment" and was therefore subject to the law of the place of payment. The second ground was that the indorser's contract called for payment at the place where the bill or note is payable and was controlled for that reason by that law. In the last place the court called attention to the fact that a contrary doctrine, which would allow recourse against the drawer and indorser before the obligation of the principal debtor had become due, would constitute a startling anomaly. As for the first ground of the decision, it has been shown that the moratory legislation may materially affect the substance of the contract of the drawer and indorser and for that reason cannot properly be regarded as relating merely to the "incidents" of presentment and payment. So far as the second ground is concerned we have seen that the great weight of American authority takes a contrary view of the place

4 (1875) L. R. 10 Q. B. 525 ; 44 L. J. Q. B. 221.

${ }^{9} 26$ L. T. Rep. (N. S.) 746 . 
where the drawer's and indorser's contracts are to be performed. The third ground of the decision is obviously inconclusive so far as its statement is concerned. It suggests, however, a line of reasoning which, if properly developed, may justify the recognition of foreign moratory legislation with respect to the American drawer and indorser.

Allatini \& Co. v. Abbott sustains the French legislation with respect to a local indorser exclusively on the ground that such indorser agreed to pay in France. In view of the fact that the American law is contrary to the English on this point this line of reasoning cannot support moratory legislation with respect to American drawers and indorsers in this country. In reply to the argument that the recognition of the foreign moratory legislation would be inequitable to the indorser, the learned court calls attention to the fact that it would be more injurious to the citizens of other countries if a universal repudiation or bankruptcy had taken place instead of an extension of the time for meeting contracts. This statement suggests the true ground upon which the recognition of foreign moratory legislation with respect to American drawers and indorsers must be based.

The recent case of In re Francke \& Rasch ${ }^{50}$ recognized with respect to English drawers the moratory legislation enacted in Germany during the present war, on the ground that the due date of the bills was, according to the provisions of the English Bills of Exchange Act, determined by the law of the place where the instrument was payable. ${ }^{51}$

(b) Pillet's view.

Pillet $^{52}$ has sought to justify the recognition of foreign moratory legislation with respect to the local drawer and indorser on the ground of "public order." The notion of "public order" plays an important part in all continental discussions of the conflict of laws, especially in France and Italy, but nobody has yet succeeded in giving an accurate idea of what is meant by it. The continental jurists deny that foreign laws can operate in a state only with the permission of such state. Some laws are deemed to have extraterritorial operation ex proprio vigore. Those that have only a territorial operation are generally said to rest upon considerations of "public order," being based generally upon economic or social grounds which make imperative the application of those laws to all persons within the territory. ${ }^{53}$ Even the rule that property rights in immovables are subject to the law of the situs is said to rest upon the same notion of "public order." Pis Pillet,

\footnotetext{
${ }^{80}$ (I9I8) 87 L. J. R. 273; 34 L. J. R. 289.

nee also Goldmuntz v. Spitzel (rgI5, N. Y. Sup. Ct.) I7o N. Y. Supp. 467, gr Misc. I48; Taylor v. Konchakji (IgI6) N. Y. L. J. 813.

${ }^{20}$ Pillet, Principes de droit international privé, 408. The same opinion has been expressed by Bonolis, 7 Il diritto commerciale, I90, and by Despagnet, 997.

${ }^{\mathrm{B}}$ See Pillet, Principes de droit international privé, 405.

${ }^{34}$ Weiss, Ig6.
} 
Despagnet and Bonolis argue from this basis that, inasmuch as moratory legislation enacted by the law of the place where the bill or note is payable, in order to be fully effective, must bind all parties to such instrument, it should be deemed to belong to the above-mentioned category of laws.

The brief statement here given of the notion of public order indicates that it is something quite different from the Anglo-American concept of public policy. The meaning of the term is too vague to be of any service to us in the discussion of the problem from an Anglo-American point of view.

(c) Diena's view.

Diena $^{55}$ takes the position that moratory legislation postponing the day of maturity is invalid as regards foreign drawers and indorsers, but he concludes that if moratory legislation allows interest it does not affect the substance of the contract but only the mode of its performance, and should be recognized on that ground. In criticism of this view it may be stated that so far as the foreign drawer and indorser are concerned, the substance of their contract is certainly affected by moratory legislation extending the time of maturity. The effect of such legislation, if binding upon them, is to keep the parties in suspense during the full time of the extensions granted as to whether or not they will be called uporr to pay. The allowing of interest to the holder in the meanwhile is of little comfort to them. The granting of interest is an important element in considering the reasonableness of the legislation as a whole, but it cannot serve as a criterion to determine whether the legislation affects the substance of the contract of the foreign drawer and indorser or merely the "form" or "incidents" of payment.

(d) Brocher's view.

Brocher ${ }^{58}$ would recognize foreign moratory legislation extending the maturity even as regards foreign drawers and indorsers from the necessities of a "good administration of justice." This conclusion in the estimation of the writer is sound but it needs to be supported by legal reasoning which the learned author fails to give.

(e) Jitta's vieze.

Professor Jitta, ${ }^{57}$ of the University of Amsterdam, emphasizes in his work La substance des obligations the fact that the problems in the conflict of laws should not be determined by rules of thumb but by the reasonable requirements of each situation. The question of the recognition of foreign moratory legislation he would submit to his usual test, namely, "what is the reasonable interpretation of the confidence inspired?" $\mathrm{He}$ would ask: Is the enactment of moratory

${ }_{3} 3$ Trattato de diritto internazionale, I89-190.

${ }^{60} 2$ Brocher, Cours de droit international privé, 334.

${ }^{\circ 7} 2 \mathrm{Jitta}, \mathrm{I} 40$. 
legislation subsequent to the execution of a bill or note such an extraordinary event that prudent men should have reasonably taken such a contingency into consideration? Professor Jitta is of the opinion that such an occurrence should have been reasonably foreseen by both parties and that the delay imposed by the law of the place of payment should therefore be recognized with regard to them. It is evident, however, that such a contingency could not be actually foreseen by the parties. Were the question asked, could $B$, when he indorsed bills of exchange on Paris, London, Brussels, Rome, etc., in May, I9I4, have reasonably foreseen that moratory legislation might be enacted by the foreign countries before the maturity of these instruments, the answer must certainly be in the negative. If the test suggested by the learned author was not intended to refer to the actual ability to foresee such an event but merely to express the idea that the recognition of such legislation is reasonable, the conclusion must be approved. Under these circumstances the real grounds for such recognition would be those of policy. Everything else is fiction.

5. Development of the true view: Vidari and Lyon-Caen \& Renault.

Vidari, ${ }^{58}$ the eminent Italian jurist and writer on commercial law, as well as some of the Italian courts, ${ }^{59}$ in sustaining the French legislation of $1870-187 \mathrm{r}$, based their conclusion in part on the ground that in the nature of things recourse cannot be taken against an indorser before the principal debtor is bound to pay. From this point of view it follows that if the law of the place of payment extends the time of payment by means of moratory legislation which the law of the forum recognizes as binding upon the principal debtor, it will also operate thus with respect to all other parties to the instrument. This line of reasoning makes the problem in its essence one of bills and notes rather than a problem in the conflict of laws. According to this view the problem in the conflict of laws is solely whether the law of the forum has accepted or incorporated the French legislation so far as the duties of the drawee or acceptor are concerned. That question being answered in the affirmative, the recognition of the moratory legislation as regards the local indorser will depend upon the nature of the indorser's contract in the law of bills and notes. According to Vidari the indorser's contract does not require presentment and protest at a time which appears definitely from the instrument itself but it will depend upon the law governing the obligation of the party primarily liable. Although this interpretation of the indorser's contract may not be the one usually found in the books it

${ }^{85}$ Vidari, Monitore dei tribunali, 1894, 99-100. The same view has been expressed by Esperson, I22; and by Götze, Allgenteine österreichische Gerichtszeitung (1871) 165.

${ }^{50}$ Cass. Turin, Mar. 6, 1872, Annali, 1872, I, I07; Monitore, 1872, 234; Cass. Florence, June 16, I873, Annali, 1873, r, 47. 
would nevertheless appear to express the true conception of the indorser's obligation. Let us see what is really meant by the indorser's contract.

Suppose that $B$ indorsed two bills of exchange in New York state on May IO, I9I4; that one of them was drawn on London and the other on Paris; and that both bills were payable three months after date. It is apparent that $B$ 's obligation is not determined by his actual intention but by the consequences attached by law to his signature on the bills. If suit is brought against him in New York there can be no question that the law of New York will determine the extent of his obligation. The consequences attached to $B$ 's signature may vary with the place upon which the bill is drawn. The law of New York may say and does in fact say that if the law of the place of payment recognizes days of grace, presentment must be made on the day prescribed by the law of such place. As the English law still recognizes days of grace, the bill drawn on London would be payable on August I3, and in case of dishonor it must be protested for nonpayment on that day. The French bill would be due on August Io, I9I4. From this it appears that the legal consequences attaching under the same law to the same act of indorsement may be different although the instruments are identical in every respect except that the one is payable in London and the other in Paris. It is also apparent that in neither case is there a duty on the holder to present the instrument for payment before the principal party was under a duty to pay according to the law of the place of payment. The holder's duty to present the instrument for payment would thus appear to be coincident with the drawee's or acceptor's duty to pay. In other words, the obligation of the drawer or indorser is to indemnify the holder in the event of dishonor by the acceptor. Such dishonor can result only from the acceptor's breach of duty to pay upon presentment of the instrument at the time of its maturity. There can be no dishonor, therefore, before the instrument is due with respect to the acceptor, and such due date is determined by the law of the place of payment. The fact that the date of original maturity has been changed by retroactive legislation which is binding upon the acceptor cannot logically affect the question.

In speaking of the French moratory legislation of $1870-187$ I LyonCaen \& Renault ${ }^{60}$ admitted in the first place that the law of the place of payment cannot bind local drawers and indorsers by moratory legislation which extends the maturity of the instrument, but they concluded that the French legislation constituted a case of vis major so far as the holder was concerned and that the delay in the present-

${ }^{\infty} 4$ Lyon-Caen \& Renault, 568. On the closely related subject of impossibility, especially impossibility by operation of law and act of state as an excuse for non-performance of contracts generally, see Comments (Igrg) 28 YaIE LAW. JouRNaI, 399. 
ment and protest caused by the French legislation would therefore be excused as regards local drawers and indorsers in all countries recognizing the defense of vis major.

The French moratory law of August I3, I870, was framed with the idea of creating a condition of vis major which would excuse the delay in presentment and protest even with respect to foreign drawers and indorsers. The French government submitted a bili according to which the maturity of all commercial paper payable between August II and September 20, I870, was postponed one month, during which time all protests, recourse and limitation of actions were to be suspended. The commission to which the bill was referred submitted to the legislature another bill which became law, extending the time for protesting, and prohibiting suit until the expiration of the extension granted. $^{\text {.1 }}$ The object of both bills was the same, namely, to relieve parties domiciled in France from the duty to pay at a certain time without injuring their credit through protest, the bringing of suits for nonpayment, or the institution of bankruptcy proceedings. The bill submitted by the commission was accepted in preference to the government bill, largely on the confident assurance of $M$. Mathieu that the legislation as passed would constitute a condition of vis major which would be recognized everywhere with respect to all parties and that the government bill was insufficient to accomplish that end. ${ }^{2}$

In this prediction, M. Mathieu was mistaken, for the Supreme Commercial Court of the German Confederation ${ }^{63}$ and the Commercial Court of Zurich ${ }^{84}$ held that even if the French legislation created a condition of vis major, that defense was not recognized under the law of Germany or the law of Zurich with respect to bills and notes, and that the defense would therefore fail against any party whose contract was governed by the German and Zurich law, respectively. But some of the courts which recognized the effectiveness of the French legislation even with respect to local drawers and indorsers did base their decision partly on the ground that by forbidding suit against the parties to bills and notes during the time for which the protest was extended the French legislation had impliedly prohibited the protesting of such bills, and that this constituted a condition of

" Journal de l'Empire française, Aug. 13, I870, p. I413, col. 56.

- Journal de l'Empire française, Aug. 13, 1870, p. I421, col. 4; Duvergier, Collection complete des lois, decrets, etc., 1870, p. 287, note.

"3ecision of Feb. 21, I87I, I R O H G, 286; I Clunet, I85; Dalloz, I872, p. $48 \mathrm{I}$, note. An abstract of the case may be found in 18 Goldschmidt's $Z$ eitschrift, 628 .

Decree of May 22, 1871, 22 Zeitschrift für Kunde und Fortbildung der zürcherischen Rechtspflege, 37r. A summary of the case may be found in I7 Goldschmidts Zeitschrift, 30r. 
vis major which would excuse a delay in presentment and protest. ${ }^{65}$ Many of the foreign jurists have taken the same view. ${ }^{\text {B }}$

This is not the place to enter upon a discussion of vis major. So far as the foreign law on the subject is of interest in connection with the topic under discussion, it will be found stated in Appendix C. In this place it must suffice to say that the term refers to the existence of a condition which will excuse presentment and protest. Let us consider the problem solely with reference to Anglo-American law. The question is the following: Must not the moratory legislation of Austria, Belgium, England, etc., be recognized under the ordinary rules of bills and notes relating to presentment and protest? According to American and. English law delay in the presentment, protest and notice is excused if such delay is caused by circumstances beyond the control of the holder and it is not imputable to his default, misconduct or negligence. ${ }^{.7}$ May not a delay in the presentment and protest caused by moratory legislation be excused on this ground? The instrument must be presented for payment at the place of payment in accordance with the law of that place. If the law of that place prohibits presentment and protest for a certain period of time it creates a legal impossibility which will excuse these acts at such place until the expiration of the prohibitive legislation. The same effect must be given to such legislation in the United States. The question thus becomes: Does the moratory legislation of foreign countries forbid presentment and protest? None of these countries prohibits these acts expressly. The Belgian legislation of the present war provides that demand is not to be made until the expiration of the

${ }^{\star}$ Cass. Turin, Mar. 6, 1872, Annali, 1872, I, I07; Monitore, 1872, p. 234; Cass. Turin, July 30, I873, Monitore, I873, p. 893; Cass. Turin, May 20, I879, Amali, I879, I, 405; Monitore, 1879, p. 636; Cass. Florence, June 16, I873, Amali, I873, r, 47; Sup. Ct. of Norway, Jan. 16, 1875, 2r Goldschmidt's Zeitschrift, 580 .

${ }^{\infty}$ Champcommunal, Anmales, I894, II, 250; Fick, 40; 4 Lyon-Caen \& Renault, no. 663; Munzinger \& Riggeler, I7 Goldschmidt's Zeitschrift, 299-300; 2 Rolin, 553-554; Vidari, 9 Archivo giatridico, I9I.

Some authors hold that an express prohibition is necessary to constitute vis major. Hovy, 48; Norsa, Monitore dei tribunali, I87I, p. 329.

A number of authors reached the conclusion that the French legislation of I870-187I prohibited merely the protest. This they held to be equivalent to a temporary abolition of the protest in France. In their opinion the holder should have presented the instrument at the time of its original maturity and upon nonpayment been allowed to take immediate recourse against the drawer and indorser without the necessity of a protest. Buscemi, 8 Archivo giuridico, 90; Guiseppe, 18 Goldschmidt's Zeitschrift, 635; Chrétien, I; Salpius, I9 Goldschmidt's Zeitschrift, 62 .

${ }^{67}$ Negotiable Instruments Law, sec. 8I, 82 (I), II2, II3, I47, I48 (2), I59; Bills of Exchange Act, secs. 39 (4), 46 (I), (2) (a), 50 (I), 50 (2) (a), $4 \mathrm{I}$
(2) (b), $5 \mathrm{I}$ (9). 
obligatory extension of time for protesting. Under such legislation it is manifest that no notary in Belgium would assume the responsibility of protesting a bill or note at an earlier date. If he did, he would incur the risk of becoming liable to the drawee or acceptor for having injured his credit through a premature protest of the bill. The moratory legislation of England, Germany and Italy postpones the day of maturity; that of Austria postpones the day of payment, while the Swiss law speaks of granting days of grace. None of these laws expressly prohibits either presentment or protest at the time of original maturity; but it is certain that no notary of the place of payment can protest a bill before the day when it is due according to the moratory legislation without risk of personal responsibility for any loss caused. So far as the protest is concerned it would therefore seem that the delay caused by moratory legislation, in whatever form it may be expressed, will be excused under the ordinary rule of Anglo-American law of bills and notes governing the time within which protest must be made. The only doubt relates to presentment. Presentment on the day of original maturity would appear to be permitted under the moratory legislation of the European countries, although it is of no legal effect so far as the principal party is concerned. The contention might therefore be made that presentment being possible, it should be made and notice of dishonor given to the drawer and indorser. It seems to the writer, however, that whenever the moratory legislation of a country operates as an obligatory extension of the time of payment, presentment on the original date of maturity cannot be required, unless such legislation is to be disregarded altogether and an immediate right of recourse is to be allowed. What does the law of New York mean when it makes presentment, protest and notice conditions precedent to the indorser's liability? It must mean presentment by a notary or other official authorized to protest negotiable paper. If no such person can act before the expiration of the moratory legislation it would inevitably follow that presentment must be excused along with the protest until that time. Were this not so, strange consequences would result. If presentment by the holder on the day of original maturity constituted a legal demand within the law of bills and notes, such demand and subsequent notice to the indorser would start the running of the statute of limitations. The holder might thus find himself in the predicament of having his action against the indorser barred before he is in a position to have the instrument protested; and before that time he cannot sue. The only way of escape from this dilemma is to allow suit without the necessity of protest, but this logically leads to total disregard of the foreign legislation with respect to such indorser. ${ }^{68} \mathrm{~A}$ choice must be made

\footnotetext{
${ }^{6}$ According to art. 53 of the Uniform Law of the Hague Convention of I9I2 relating to bills and notes the holder must notify his indorser immediately
} 
between the following alternatives: We must either recognize the foreign moratory legislation and hold that both presentment and protest are postponed until after the expiration of the extensions granted, or we must disregard it and allow an immediate right of recourse without the necessity of protest, if upon presentment at the time of original maturity the drawee fails to pay. In the opinion of the writer policy demands the adoption of the former alternative. ${ }^{69}$

On grounds of equity and fairness to the indorser the courts should impose upon the holder of the instrument at the time of original maturity the burden of showing that the indorser had actual knowledge of the existence of the foreign moratory legislation or that he gave notice thereof to such party within a reasonable time after the date of original maturity. ${ }^{70}$ Such a notice might enable the party secondarily liable to protect his interests by keeping the contingent liability in mind, which but for such notice he might consider discharged. Suppose, however, that no notice was given and that the bill is transferred before the date of its ultimate maturity to a holder for value who has no knowledge of the facts. Would he have the rights of a holder in due course? The answer must clearly be "yes," if the moratory legislation postpones the maturity of the instrument. A country recognizing such legislation must hold that any negotiation before the date of final maturity is in due course. There is more room for doubt where the legislation does not purport to change the date of maturity but postpones merely the time for protesting.

\section{CONCLUSION}

The courts and writers that have refused recognition to moratory legislation of the place where the bill or note is payable, with respect to the local drawer or indorser, have done so because they deemed such legislation inconsistent with the contract of such party. They have erroneously assumed that the contract of each individual party to a negotiable instrument has an invariable content which is fixed

of the existence of vis major and indicate the fact on the bill or note. If the condition of vis major continues longer than thirty days after the maturity of the instrument recourse may be taken without the necessity of presentment and protest. This convention has not been ratified as yet by any of the continental countries. Austria has adopted the provisions of the above article, however, in a law of Nov. 30, Igr2. (Reichsgesetzblatt, IgI2, n. 2I5.) It is probable that art. 53 was not intended to apply to moratory legislation. See Langen, Der deutsche Entwurf einer Wechselordnung, 76 Goldschmidt's Zeitschrift, 52.

${ }^{\infty}$ Rolin holds that legislative postponement of maturity involves in the very nature of things an implied prohibition of presentment and protest. 2 Rolin, pp. 553-554.

${ }^{70} \mathrm{~A}$ similar requirement laid down by the Supreme Court of the United States in Harris v. Balk (I905) I98 U. S. 215, might be invoked by way of analogy. 
by the parties themselves. This assumption is, however, contrary to fact. It has been shown above that the same signature to instruments that are absolutely identical except as regards the place of payment may have different legal consequences. The existence of war may make the presentment of a bill at the place of payment impossible and may consequently extend for months and even years the time within which the indorser may be called upon to pay. Such was certainly not the intent of the indorser nor could that contingency have been reasonably within his contemplation; yet he is bound because the law (Anglo-American law) so wills. Rules of law are based upon considerations of policy. In the same manner the problem of the recognition of foreign moratory legislation is in the last analysis a question of policy. There are two questions to be answered. The first is, shall our courts excuse a delay in presentment and protest only if the delay is caused by obstacles of a physical nature and not when they are imposed by the law of the place where the acts must be done? The answer to this question is clearly "no." The other question is whether a distinction should be made between different forms of moratory legislation. Technical reasoning might suggest as did M. Mathieu in I870 that such legislation must not affect the maturity of bills and notes but merely interpose legal obstacles to the ordinary presentment and protest. Even the French legislator of I870-7I appears to have realized in the end, however, that the difference between extending the time for protest for a period of eleven months and extending the maturity of bills and notes for a like period was purely technical. ${ }^{71}$ The fact that nearly all of the countries that have enacted moratory legislation during the present war have postponed maturity directly would also tend to prove that such a distinction has no reasonable basis. So far as the different parties are concerned it matters little to them in what form the moratory legislation is expressed. If it be remembered in addition that this kind of legislation is passed under circumstances of the greatest haste and at a time when the minds of the legislators are greatly disturbed, it seems especially unwise to make the recognition or nonrecognition of moratory legislation enacted at the place of payment depend upon considerations of mere form.

The ultimate question is therefore whether there are controlling considerations of policy which should induce the law of the forum to incorporate the foreign law inclusive of its moratory legislation. That there are the strongest economic reasons why the courts of New York should incorporate as a part of the law of the place of payment

\footnotetext{
7h This would appear from the fact that the laws of Apr. 26 and July 4, 187r, called the legislation laws on the "postponement of the maturity" of negotiable instruments. The original law, of August 13, 1870, postponed "the time for protesting.".
} 
the French moratory legislation relating to bills and notes, has been pointed out by Sir Philip Francis in the case of Allatini \& Co. $v$. Abbott, when he recognized the French moratory legislation of I870-I87I. He says:

"The rule of comity must be qualified so that the established and fair principle of a contract should not be violated. . . . Under the exceptional state in which France found herself it was not inequitable and it would have been more injurious to citizens of other countries if a universal repudiation or bankruptcy had taken place in commerce instead of the time for meeting contracts being extended."72

The same considerations apply with even greater force to the conditions presented by the present world conflict.

There are also political considerations of the most imperative character which cannot be ignored. The moratory legislation in question was passed by the foreign countries under circumstances of the gravest necessity. In order to make this legislation fully effective it must operate not only with respect to parties living in the country, but also with respect to all other parties on the instrument. The instruments under discussion were payable abroad. The countries in question thus had a direct connection with the contract. In view of all these circumstances there can be no doubt that the refusal of the American courts to recognize with respect to American drawers and indorsers the authority of the place of payment to enact moratory legislation would be regarded as the expression of an ungenerous and unfriendly attitude. This country is vitally interested in the growth of its foreign commerce, which depends in large measure upon the good will entertained toward the United States by the people of foreign countries, and this good will would be seriously affected by our refusal to recognize foreign moratory legislation. Nor can the fact be ignored that the United States may be compelled at some future time to pass moratory legislation. We should expect foreign countries to respect our legislation and we must be willing, by way of reciprocity, to accord the same treatment to their legislation.

So far we have considered the recognition of foreign moratory legislation with respect to persons whose contracts were executed in this country. We must briefly consider, in conclusion, the effect of such legislation if the contracts are made abroad. Suppose that a note is executed in France and is payable there, or that a bill is drawn, accepted and payable in France and that suit upon such instrument is brought in New York before the expiration of the moratory legislation. As the contracts of the maker and acceptor are executed in France and are to be performed in France, there can be no doubt that the New York courts would adopt the French moratory legislation and

${ }^{72} 26$ L. T. Rep. N. S. 746. 
determine the rights of the parties accordingly. The only possible contention to the contrary might be that the incorporation of the statute would be contrary to natural justice or good morals because it impairs the obligation of the contract. We have seen above, however, that the constitutional provisions in this country have no applicaton to the case and that they do not establish public policy which would preclude the recognition of such foreign moratory legislation. ${ }^{73}$

A graver problem is presented if we assume in the above cases that the note is payable in New York and that the bill was accepted in Paris but was payable in New York. No such question would arise if the French decrees had followed the example of the Italian and German governments, which limit the application of the moratory decrees in express terms to instruments payable in their respective countries. Unfortunately neither the French nor the Austrian decrees are so specific. $^{74}$ They postpone the maturity of negotiable instruments in general terms without indicating whether or not they are intended to apply only to instruments payable within such state. A case decided by the Supreme Court of New York ${ }^{75}$ at Special Term has assumed that the French moratory decrees postponed the maturity of a bill which was accepted in Paris but was payable in New York. In the opinion of the writer this assumption is not well founded. Although the French and Austrian moratory decrees are not limited expressly in their application to instruments payable in such countries, such a limitation must be reasonably understood. The moratory legislation under consideration was enacted for the benefit of the local financial system, which had suffered a severe shock as the result of the war, with a view to helping it adjust itself to the new conditions. In order to accomplish this object it must necessarily affect all payments by bill or note within its borders, without respect to the place where the particular contract may have been entered into. But this is the limit to which it can reasonably go. There is no adequate reason why it should attempt to postpone the payment of debts which may have been incurred in France but are payable elsewhere. In the absence of mandatory language to the contrary, the general language used must be limited in its operation by the economic object sought to be attained.

Should the French courts place a contrary construction upon the French decrees, the New York courts would be bound to disregard such interpretation. The extent to which the courts of New York will incor-

\footnotetext{
${ }^{73}$ To the same effect Goldmuntz v. Spitzel (I9I5, N. Y. Sup. Ct.) I7o N. Y. Supp. 467 ; 9r Misc. 148.

${ }^{74}$ The Belgian decrees postpone the time for protesting. This indicates clearly that the moratorium is intended to apply only to instruments to be protested in Belgium. The original Swiss decree allows an extension of thirty days by way of grace. This language is sufficient to show that the decree had reference only to instruments payable in Switzerland.

${ }^{75}$ Taylor v. Kouchakji (I916) N. Y. L. J. 813.
} 
porate the French moratory decrees will depend upon what they consider just and expedient. What the French law and the French courts may say upon the subject is not controlling. If the New York courts determine the obligation of a contract according to the law of the place of performance they would naturally decline to adopt the. French decrees to any extent. Should they determine it according to the law of the place of execution they might be disposed to hold that subsequent modifications of the obligation should be controlled by the same law. Such a conclusion does not follow, however, even if it were conceded that one and the same rule should on principle govern the creation of the contractual obligation and its subsequent modification. Rules cannot be applied in a hard and fast way, irrespective of the practical objects to be attained, but must be adjusted to those ends. The question would therefore be whether there is a sufficient foundation for the application of the lex loci contractus to moratory legislation. If the reasonable object of such legislation requires its application only to instruments payable in such country, the New York courts would not only be warranted in holding the validity and effect of moratory legislation to be subject to the law of the place of payment, but they would be bound to do so on principle.

The writer would submit that moratory legislation enacted at the place of payment should be recognized by the American courts, even as regards local drawers and indorsers, but that moratory legislation enacted by the law of the place where the contract is entered into should not be regarded as binding.

\section{APPENDIX A \\ MORATORY LEGISLATION RELATING TO BILLS AND NOTES ${ }^{1}$}

\section{Current Legislation}

Moratory legislation relating to bills and notes was enacted after the outbreak of the present war in England and in nearly all of the continental countries; also in a number of South American countries, including Argentina, Brazil and Chile. Of the continental countries it would seem that Holland alone did not find it necessary to pass such legislation, and in the United States no such legislation was passed.

\footnotetext{
${ }^{1}$ The legislation of the present war has been made accessible to the writer through the courtesy of the Harvard Law School. The Austrian and German legislation could be followed only to the end of IgI5 and the Swiss legislation to the end of IgI4. In regard to Belgium the writer has been forced to rely for the legislation and decrees of the Belgian government upon a work by Henri Masson, entitled Le législation de guerre, published in I9I7, and for the decrees by the German governor-general upon the work of Huberich and Nicol-Speyer, entitled German Legislation for the Occupied Territories of Belgium, vols. I-II, The Hague, I9I5-1917-(cited below "Huberich").-The French legislation is complete up to Jan. I, Igr8.
} 
The moratory legislation relating to bills and notes has taken very different forms, the principal types of which will be set forth in the following pages.

England. The payment of certain bills of exchange was postponed by a royal proclamation of Aug. 2, which provided as follows:

"If on the presentation for payment of a bill of exchange, other than a cheque or bill payable on demand, which has been accepted before the beginning of the fourth day of August nineteen hundred and fourteen the acceptor re-accepts the bill by a declaration on the face of the bill in the form set out hereunder, that bill shall, for all purposes, including the liability of any drawer or indorser or any other party thereto, be. deemed to be due and be payable on a date one calendar month after the date of its original maturity instead of on the date of its original maturity, and to be a bill for the original amount thereof increased by the amount of interest thereon calculated from the date of re-acceptance to the new date of payment at the Bank of England rate current on the date of the re-acceptance of the bill."

This proclamation was confirmed on Aug. 3 by an Act of Parliament, known as the Postponement of Payments Act, ${ }^{3}$ which conferred authority on the king to postpone the payment of any bills of exchange, negotiable instruments and any other contract obligations. The act provided that it was to remain in force for a period of six months.

On Aug. 6 a First Proclamation was made which extended the Proclamation of Aug. 2 to certain other payments." On Aug. I2 a Second General Proclamation extended the Proclamation of Aug. 6.5 On Sept. I a proclamation was made which varied the Proclamations of Aug. 2, 6, and $12,{ }^{6}$ but this proclamation was revoked by the Third General Proclamation of Sept. $3 .^{7}$ The latter varied the Proclamations of Aug. 2, 6, and 12 and revoked the proclamation of Sept. I. So far as it affects the payment of bills of exchange covered by the Proclamation of Aug. 2 it provides as follows:

"I. If on the presentation for payment of a bill of exchange which has before the fourth day of September, nineteen hundred and fourteen, been re-accepted under the terms of Our said Proclamation, dated the second day of August, nineteen hundred and fourteen, the bill is not paid, then, the said Proclamation shall, in its application to that bill, have effect as if the period of two calendar months had been in the Proclamation substituted for the period of one calendar month, and the sum mentioned in the form of re-acceptance under the said Proclamation shall be deemed to be increased by the amount of interest on the original amount of the Bill for one calendar month calculated at the Bank of England rate current on the date when the bill is so presented for payment as aforesaid. . . . . . . .

\footnotetext{
'Pulling, Manual of Emergency Legislation (1914) 238-239.

4 \& 5 George V, ch. Ir.

- Pulling, op. cit. I9r4, p. $239 . \quad$ 'Pulling, I9I4, p. 242.

'Pulling, I9I4, p. 24r. 'T Pulling, I9I4, p. 244.
} 
3. Nothing in this Proclamation shall affect the payment of interest under the Proclamations extended thereby, or prevent payments being made before the expiration of the period for which they are postponed."

On Sept. 30 a Final General Proclamation ${ }^{8}$ was made which provided that the moratorium should terminate on Nov. 4, I9I4.

Austria. By an imperial decree of July 3 I, I9I $4,{ }^{9}$ the time for payment (Zahlungszeit) of bills, notes and checks falling due between Aug. I and I4, and the time for their presentment for acceptance and payment and for their protest were postponed (gestundet) fourteen days. Interest was to be payable from the date of original maturity.

By an imperial decree of Aug. I3, I91 $4,^{10}$ such time was extended sixty-one days with respect to bills, notes and checks that had been issued before Aug. I, I9I4, and were due between Aug. I and Sept. 30. Interest was to be payable as before.

The third imperial decree, of Sept. 27, 1914,,$^{11}$ inaugurated a plan for the gradual termination of the moratorium. Twenty-five per cent of the original amount was to be paid at specified times on bills, notes and checks issued before Aug. I and falling due on or before Nov. 30 . The balance was postponed to Nov. 30 , if the instrument was due before Oct. I, and sixty-one days if it fell due between Oct. I and Nov. 30 . If the part payment was not made as provided by the decree, protest was to be made and notice of dishonor given in accordance with arts. 45 and 47 of the Bills of Exchange Law. Interest on the postponed amount was to be paid. It also provided that an insuperable obstacle should excuse presentment and protest until the disappearance of such obstacle and ten business days thereafter.

A fourth imperial decree, of Nov. 25, rgr $4,{ }^{12}$ provided for the payment of an additional amount of $25 \%$ on the above instruments and a first payment of $25 \%$ on bills, notes and checks falling due in September and October. The balance on the above instruments was postponed to Feb. I, I9I5. The provisions relating to protest, notice and interest were like those of the preceding decree, except that it authorized a substitute for formal protest in the form of a declaration in a specified form.

The fifth imperial decree, of Jan. 25 , $1915,^{13}$ continued the legislation with respect to payment and provided that the balance be postponed until May 3I, I9I5. This decree authorized the courts to grant extensions to parties having their residence or place of business within the theater of war and a restitution of rights if their residence or place of business was in a part of the empire in which the courts had

- Pulling, I9I4, p. 246.

'Reichsgesetzblatt, I914, no. I93.

${ }^{10}$ Reichsgesetzblatt, 1914, no. 216 .
${ }^{11}$ Reichsgesetzblatt, 1914, no. 26r.

${ }^{12}$ Reichsgesetzblatt, 1914, no. 32I.

${ }^{13}$ Reichsgesetzblatt, 19I5, no. 18. 
ceased to sit. It introduced also the principle of reciprocity, according to which foreign subjects having their residence or place of business within the empire were to be unable to enforce greater rights against Austrian subjects than the latter, if they resided abroad, could enforce in such foreign country against subjects thereof.

A sixth decree, of May 25, I9I 5 , $^{14}$ brought the above legislation to a close by specifying the time when the full amount on bills, notes and checks which were issued before Aug. I, I9I4, and fell due between Nov. I, I9I4, and Jan. 3I, IgI5, was to be paid.

A decree of the Minister of Justice of June $17,1915,{ }^{15}$ provided with respect to bills, notes and checks, payable in full or in part in the months of July and August, 1915, that the presentment for payment and the making of the protest were to be deemed in due time if made within six business days after the date of maturity. Notice might be given within six business days.

The military events in Galicia and Buckowina in the fall of $19 \mathrm{I}_{4}$ made special legislation with reference to these parts of the empire necessary. By an imperial decree of Oct. I3, I9r $4,{ }^{16}$ all necessary changes in the moratorium with respect to these districts were authorized to be made by ministerial decrees. Such decrees were made on Oct. I $3{ }^{17}$ I9I4, Nov. 25, I9I4, ${ }^{18}$ Jan. 25 , I9I $5,{ }^{10}$ May 25 , I9I $5,{ }^{20}$ Sept. $17,1915,{ }^{21}$ and subsequently. During the years I9I4 and I9I5 they followed in outline the general decrees above mentioned. The principal difference consisted in the fact that none of them called for payment, in full or in part. Instead, the time for presentment.and for protest was extended from time to time with respect to the entire amount specified in the instrument.

A ministerial decree of June 28 , I $915,{ }^{22}$ introduced special provisions with respect to certain southern districts of the empire (Dalmatia, etc.). This decree provided with respect to bills, notes and checks payable in the above districts that if presentment or protest was to be made later than May 2I and was not made in due time the legal presumption should be that it was prevented by vis major.

Belgium. By a royal decree of Aug. 2, $19 \mathrm{I}_{4}{ }^{23}$ the time for protesting and all other acts necessary for the preservation of recourse on negotiable instruments issued before the publication of the decree was extended to Aug. 3I, inclusive. Payment could not be demanded during that time. Interest was to be paid from the date of original maturity.

${ }^{14}$ Reichsgesetzblatt, 1915, no. I38.

${ }^{15}$ Reichsgesetzblatt, 19I5, no. I68.

${ }^{16}$ Reichsgesetzblatt, I914, no. 278 .

${ }^{17}$ Reichsgesetzblatt, 1914, no. 279.

${ }^{18}$ Reichsgesetzblatt, 1914, no. 322.

${ }^{23}$ Masson, Législation de guerre, 6I ; Moniteur belge, Aug. 3, 19r4, no. 215.
${ }^{10}$ Reichsgesetzblatt, 19r5, no. x9.

${ }^{20}$ Reichsgesetablatt, I9I5, no. I39.

${ }^{21}$ Reichsgesetzblatt, I9I5, no. 273.

$=$ Reichsgesetzblatt, I915, no. 184 . 
The above decree was confirmed by the law of Aug. 4 (art. 4, 2). ${ }^{24}$

By a decree of Aug. $6^{25}$ the time during which protest and the other acts might be made was extended to Sept. I5, inclusive. Payment was not to be demanded in the meanwhile. According to Henri Masson, La législation de Guerre, the last decree was repealed and replaced by a decree of Aug. 24, which provided that the time of all negotiable instruments falling due before Sept. I3, I9I4, should be extended, irrespective of their date of execution, to Sept. 15 , I9I4. ${ }^{26}$ By a decree of Sept. I2 the time was extended to Oct. $12{ }^{27}$ Further extensions have been granted by later decrees of the Belgian government. ${ }^{28}$

The German government after its occupation of Belgium issued various decrees with reference to bills and notes. The first of these, issued by the Governor-General on Sept. 1o, $1914,{ }^{29}$ extended the time for protesting granted by the royal decrees of Aug. 2 and 6, to Sept. 30, I9I4. The time was further extended one month each by the decrees of Sept. $23,{ }^{30}$ Oct. $21,{ }^{31}$ Nov. $20,{ }^{32}$ Dec. I8, I9I4, ${ }^{33}$ Jan. $20,{ }^{84}$ Feb. 20, ${ }^{85}$ Mar. 2I, ${ }^{36}$ Apr. 21, ${ }^{37}$ May 22, ${ }^{38}$ June 23, ${ }^{39}$ July 2I, ${ }^{40}$ Aug. $20,{ }^{41}$ Sept. $20^{42}$ and Oct. 21 , $1915 .{ }^{43}$ The latter provided that the holder must give notice to his debtor of the fact that he held the instrument. If no notice was given, such holder was to lose interest from Jan. I, I9I6.

A decree of Dec. 17 , I9I $5,{ }^{44}$ allowed a further extension to Jan. 3I, I9I6.

By a decree of Jan. 5, I9I6,45 provisions were made for the gradual termination of the moratorium. According to art. I the time for presentment and protest of all bills, notes and checks for more than 200 francs issued before Aug. 3, I914, within the "Generalgouvernement" of Belgium and payable therein between July $3 \mathrm{I}$, I9I4, and Jan. $3^{\mathrm{I}}$, I9I6, inclusive, was extended until the expiration of nineteen months and seven days from the date of original maturity, which period was not to extend, however, beyond Aug. 8, I9I6. If issued outside of the above territory or if the instrument was for 200 francs or less, the extension was to be twenty-two months and seven days,

${ }^{24}$ Masson, 6r.

${ }^{25}$ Masson, 6r ; Moniteur belge, Aug. 9, 19r4, no. 22x.

${ }^{28}$ Masson, 62.

${ }^{27}$ Masson, 62.

${ }^{36}$ Huberich, 2nd ser. p. 15 r.

${ }^{23}$ Masson, 62.

${ }^{20}$ Huberich, Ist ser. p. 7 .

${ }^{80}$ Huberich, Ist ser. p. I6.

${ }^{\text {a1 }}$ Huberich, rst ser. p. 24.

"Huberich, Ist ser. p. 45.

${ }^{35}$ Huberich, Ist ser. p. 93.

at Huberich, and ser. p. 50.

${ }^{3}$ Huberich, and ser. p. IO4.

${ }^{57}$ Huberich, 3rd ser. p. 27.

${ }^{3}$ Huberich, 3rd ser. p. 46.

${ }^{30}$ Huberich, 3rd ser. p. I33.

suberich, 4th ser. p. 43.

"Huberich, 4th ser. p. I73.

"Huberich, 4th ser. p. 317.

${ }^{* 3}$ Huberich, 5th ser. p. 74.

"Huberich, 5th ser. p. 237.

s Huberich, 6th ser. p. 6. 
which period was not to extend, however, beyond Nov. 8, I9I6. Payment was not to be demanded of any party before the expiration of such time. Protest was to be made only during the last seven days of the extension. Interest was to be paid in accordance with the provisions of the existing legislation. The ordinary time for protesting instruments payable within the territory of the "general government" on Feb. x, I9I6, or later, was to be extended five days. The ordinary time allowed by the Belgian commercial code for bringing an action of recourse (bk. I, tit. 8, arts. 56,58 ) was extended two weeks.

The above decree was not to apply to the French part of the "general government."

The only other decree that the writer has been able to find relating to the Belgian moratory legislation so far as it concerns bills and notes is a decree of the German Governor-General of Sept. 12, 1916, ${ }^{48}$ which applies the decree of Jan. 5, I9I6, with certain modifications, to the districts of East Flanders which had been added to the territory of the "general government" by the decree of July 2I, I9I6. ${ }^{47}$

The decree of the German Governor-General of Aug. 5, 19I6, covered the subject of moratory legislation in general. Masson states that the Belgian government has.declined to recognize the validity of the decree. He is himself of the opinion that the decree violated art. 43 of the Règlement of the Hague Peace Convention. ${ }^{48}$

France. The law of Jan. 27, I910, ${ }^{90}$ authorized the Council of Ministers in case of war, or other great public calamity or interruption of the postal service, to extend by decree "the times in which protests and all other acts necessary for the preservation of recourse with respect to all negotiable instruments (valeurs negociables) might be made." In order to make it clear that the government might extend the maturity of negotiable instruments, a law of Dec. 24, 1910, ${ }^{50}$ was passed which conferred this power expressly under the same terms and conditions as those provided in the law of Jan. 27. A law of Aug. 5, 1914, ${ }^{51}$ defined the meaning of valeurs negociables in the above laws and authorized the government to suspend by decree the effects of commercial and civil obligations.

The French moratory legislation of the present war begins with the decree of July $3 \mathrm{I}, \mathrm{I} 9 \mathrm{I} 4{ }^{52}$ by which the time for protesting and for all other acts required for the preservation of recourse of negotiable

Huberich, 8th ser. p. 508.

7 Huberich, 8th ser. p. I72.

¿3asson, Législation de guerre, 1917, pp. 68-70.

"Duvergier, I9Io, p. 93.

${ }^{\text {so }}$ Duvergier, rgro, p. 698.

so Journal officiel of Aug. 6, I9I4; I Dalloz, Guerre de 1914, documents officiels, 37; Lois nouvelles, I914, p. 3II; I Sirey, Législation de la guerre, I9I4-Igr6, p. 33.

${ }^{2}$ Lois nouvelles, 1914, p. 309; Sirey, I, 3. 
instruments (valeurs negociables) issued before Aug. I, rgr4, and falling due between Aug. I and Aug. I5, was extended thirty days. A like extension was granted with respect to all negotiable instruments falling due before Aug. 15 , I9r4. A decree of Aug. $5^{53}$ extended the above decree to instruments falling due on July $3 \mathrm{I}$, 19r4. By art. I of the decree of Aug. 9, I9I4, the maturity of bills and notes falling due since July 3I, I9I4, and before Sept. I, I9I4, was extended thirty days, provided they were executed before Aug. 4, I9I4. Nothing is said about the payment of interest.5t By art. I of the decree of Aug. $29^{55}$ the maturity (échéance) of negotiable instruments executed before Aug. 4, I9r4, and falling due between July $3 \mathrm{I}$ and Sept. 30 was extended another thirty days. Instruments executed on Aug. 4, Igr4, or later were to be payable at the time of their maturity. The presentment of such instruments, and in case of nonpayment the making of the protest were to be made within ten days, inclusive of the day of maturity. Art. 6 of the decree provided that the extensions granted by the decrees of July $3^{\mathrm{I}}$ and of Aug. 5 and by the present decree were optional as regards the debtor and that the latter, by availing himself thereof, was to be chargeable with interest at the rate of $5 \%$, which was to run from the day following the day of original maturity.

A decree of Sept. 27, I9I4 (art. I) ${ }^{56}$ extended the above periods another thirty days with respect to instruments issued before Aug. 4 and maturing before Nov. I, IgI4. By art. I of the decree of Oct. 27 , $1914{ }^{57}$ the maturity of instruments executed before Aug. 4, I9I4, and falling due before Jan. I, I9I5, was extended sixty days. The new extension was not to be granted to debtors who had not been called to the colors nor were domiciled in such parts of the invaded territory to be specified by decree, except under the conditions mentioned in the following article. This article (art. 2) suspended arts. I6I-I72 of the French Commercial Code, relating to presentment, protest, etc., until the expiration of the period granted by art. I. During the last thirty days of such extension the holder might demand payment provisionally (à titre provisoire). In case of nonpayment the default in payment might be proved by registered letter and notice of receipt. Suit might be brought without protest within two weeks after notice of receipt but only with the permission of the president of the civil court.

Decrees similar to the last, extending the time of maturity now sixty, now ninety days, were made on Dec. 15 , I9I4, ${ }^{58}$ Feb. 25,

${ }^{*}$ Lois nouvelles, 1914, p. $3 \mathrm{II}$; Sirey, I, 33.

${ }^{84}$ Dalloz, 1914, I, p. 58; Lois nouvelles, 1914, p. 312; Sirey, I, 4I.

${ }^{\infty}$ Dalloz, I, I25; Lois nouvelles, 1914, p. 32I; Sirey, I, 89.

"Dalloz, I, 167; Lois nouvelles, 19I4, p. 324; Sirey, I, 128.

"Dalloz, II, 38; Lois nouvelles, I9I4, p. 368; Sirey, I, 175.

"Dalloz, II, 205; Lois nouvelles, r915, p. 2; Sirey, I, 259. 
I9I $5{ }^{58}$ and Apr. I5, I9I5. ${ }^{60}$ The last added that the holder of an instrument whose maturity was postponed must notify his debtor before May 3I, I9I5, of the fact that he holds the instrument and that payment may be made to him. Failure to give notice was to result in a forfeiture of the interest mentioned, from May $3 \mathrm{I}$, I9I5.

Decrees of June $24,{ }^{61}$ Oct. $16,{ }^{62}$ and Dec. 23 , I91 $5,^{63}$ of Mar. $18,{ }^{64}$ June $21,{ }^{65}$ Sept. $19^{66}$ and Dec. I9, $1916{ }^{67}$ of Mar. $17{ }^{68}$ June $19,{ }^{69}$ Sept. $25^{70}$ and Dec. 27 , I9I7, ${ }^{71}$ granted other extensions under conditions similar to those contained in the decree of Apr. I5, 19I5. The decree of Dec. 27, I9I7, extended the benefit of the moratorium to all negotiable instruments executed before Aug. 4, I9I4, and falling due before Apr. I, I9r8.

Another decree of Dec. $23,1915,{ }^{72}$ provided for the termination of the moratorium with respect to debtors who,

"on account of the state of war have become contractors of the home government or of the governments of the allies, or who work for the account of these states as principals or subcontractors or who furnish to such persons raw materials or goods partly or wholly manufactured, or who assisted to some extent in their manufacture."

The payment of instruments issued before Aug. 4, 19I4, and falling due originally after July 3r, I9I4, was postponed twenty months from the date of original maturity. The debtor was allowed to make part payment provided it was not less than a specified amount. Protest was prohibited, and nonpayment was to be proved by registered letter and notice of its receipt. The courts were authorized to grant to the debtor within the last thirty days prior to maturity further extensions of time for payment. Additional extensions might be granted subsequently. Suit might be brought ten days after receipt of the registered letter without the necessity of a protest-but only with the permission of the president of the commercial court.

A decree of Dec. 29 , $1917,{ }^{73}$ provided for the termination of the

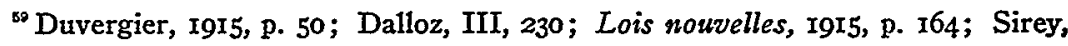
II, 43.

${ }^{\infty}$ Duvergier, I915, p. I27; Dalloz, IV, I66; Lois nouvelles, I915, p. 209; Sirey, II, II8.

${ }^{61}$ Duvergier, I915, p. I95; Dalloz, V, I09; Lois nouvelles, 1915, p. 348; Sirey, II, 207.

Duvergier, I915, p. 3I4; Dalloz, VII, 30; Lois nouvelles, I915, p. 437; Sirey, III, 80.

${ }^{3}$ Duvergier, I915, p. 4I4; Sirey, III, 203.

ss Dalloz, X, 200.

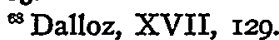

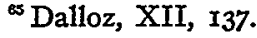

${ }^{60}$ Dalloz, XIX-XX, 69.

${ }^{\infty}$ Dalloz, XIV, 24.

${ }^{87}$ Dalloz, XV, 130 .

${ }^{70}$ Dalloz, XXI-XXII, 229.

${ }^{72}$ Duvergier, I915, p. 4I5 ; Sirey, III, 205.

${ }^{71}$ Dalloz, XXIII-XXIV, 264.

${ }^{72}$ Dalloz, XXIII-XXIV, 3rr. 
moratorium with respect to debtors who had enjoyed exceptional war benefits as defined by the law of July I, 1916. ${ }^{.4}$ As regards such persons all negotiable instruments issued before Aug. 4, I9I4, and falling originally due after July $3 \mathrm{I}$, I9I4, were to be due forty-eight months from the date of original maturity. This decree did not apply to the persons mentioned in the decree of Dec. 23 , I9I5. The provisions of the latter decree relating to part payment, protest, judicial extensions of the time for payment, and the time for bringing suit are followed in this decree.

Germany. ${ }^{75}$ On Aug. 6, $1914,{ }^{76}$ the period for presentment and protest of bills, notes, and checks was extended by a decree of the Federal Council thirty days so far as they had not already expired on July.3I, r9r4. On Aug. Io the maturity of all bills and notes executed abroad before July $3 \mathrm{I}, \mathrm{I} 9 \mathrm{I} 4{ }^{77}$ and payable in Germany, was extended three months, unless they were already dishonored on July 3 I, I9r4. In conformity with a decree of Aug. $12{ }^{78}$ such instruments were to carry interest for the three months at the increased rate of $6 \%$.

The maturity of the above instruments was extended another three months by a decree of Oct. 22 , I9I $4{ }^{79}$ with the same provision for interest for the six months. By a decree of Jan. 18 , I9I $5^{80}$ the maturity of these instruments was extended another three months. Interest was to be allowed, however, for the time extended (nine months) only if the drawee or other person at whose place of business the instrument was payable had been notified by the holder within the week preceding the time of maturity resulting from the decree of Oct. 22, I9I4, that the instrument was in his possession. The drawee was authorized to pay on the day of payment resulting from the decree of Oct. 22, I9I4, or within one week thereafter.

According to a decree of May I7, I9I 5, , all extensions of time for the presentment and protest of bills, notes and checks, granted by the decree of Aug. 6, I9I4, so far as they were still running, were to cease on June 30 , I9I $5 .^{82}$

\footnotetext{
"Dalloz, XII, 177.

Tsee Appendix C, infra.

${ }^{70}$ Reichsgesetzblatt, I914, p. 357 ; I Kriegsnotgesetze, $76 \mathrm{r}$; 76 Goldschmidt, 498.

${ }^{\pi 7}$ Reichsgesetzblatt, 1914, p. 368; I Kriegsnotgesetze, 80; 76 Goldschmidt, 504 .

${ }^{73}$ Reichsgesetablatt, I9r4, p. 396; I Kriegsnotgesetze, 86; 76 Goldschmidt, 505.

Reichsgesetzblatt, I914, p. 448; 2 Kriegsnotgesetze, $5 ; 76$ Goldschmidt, 524.

${ }^{\infty}$ Reichsgesetzblatt, I915, p. 23; 3 Kriegsnotgesetze, I36; 77 Goldschmidt, I29.

Reichsgesetzblatt, I915, p. 284; 6 Kriegsnotgesetze, 38; 77 Goldschmidt, 490.

8 Payments to enemy countries directly or indirectly were prohibited by the following decrees. With respect to Great Britain, Ireland, and the British colonies, by decree of Sept. 30, I9I4, Reichsgesetzblatt, I9I4, p. 421 ; I Kriegsnotgesetze, I76; 76 Goldschmidt, 519 .

With respect to France, by decree of Oct. 20, I9r4, Reichsgesetzblatt, 1914, p. 443; 2 Kriegsnotgesetze, 7 ; 76 Goldschmidt, 522.

With respect to Russia, by decree of Nov. I9, I9I4 (Reichsgesetzblatt, I914,
} 
Special decrees were made with reference to Alsace-Lorraine, the Prussian province of East Prussia and portions of the province of West Prussia.

By a decree of Aug. 29, $1914^{83}$ the periods for presentment and protest granted by the decree of Aug. 6, I9I4, were extended thirty days with respect to bills, notes and checks payable in Alsace-Lorraine, in East Prussia and in certain districts of West Prussia. By a decree of Sept. $8^{84}$ this legislation was extended to include the district of Danzig. Further extensions of thirty days each with respect to Alsace-Lorraine, East Prussia, West Prussia and Danzig were granted by the decrees of Sept. 24, I9I $4,{ }^{85}$ Oct. 22 , I9I4, ${ }^{86}$ and Nov. 23, I9I4 ${ }^{87}$ The decrees relating to these parts were revoked by the decree of Dec. $17,1914{ }^{88}$ in which it was provided that the periods for presentment and protest, unless they had already expired on July 3I, I9I4, or a later time should be allowed by other provisions, should expire as follows:

I. If the day on which the instrument was payable (Zahlungstag) or the day from which the period within which presentment and protest must be made began to run was before Jan. I, I9I 5, the extension was to be five months from the beginning of such period, which day was to be, at the earliest, Feb. I, I9r5.

2. If the day on which the instrument was payable or the day from which the period within which presentment and protest must be made began to run was Jan. I, I915, or later, the time was to expire on May 3I, I9I5.

By a decree of Jan. 2I, I91 $5,^{89}$ the period was extended from Feb, I, I9I5, to Mar. 3I, I9I5.

A decree of Mar. 4, 1915, ${ }^{90}$ revoked the decrees of Dec. I7, I9I4, and of Jan. 2I, I9I5, except so far as they revoked prior provisions.

p. 479; 2 Kriegsnotgesetze, 18) and decree of Feb. 4, 19I5, Reichsgesetzblatt, I915, p. $69 ; 4$ Kriegsnotgesetze, $47 ; 77$ Goldschmidt, 132 .

With respect to Egypt and French Morocco, by decree of Oct I5, I915, Reichsgesetzblatt, I9I5, p. 673; II Kriegsnotgesetze, 54; 78 Goldschmidt, 467.

The decrees subsequent to Oct. 15,1915 , are inaccessible.

The time for presentment and protest for bills, notes and checks whose payment was prohibited by the above decrees was extended until after the expiration of such decrees. The time for presentment and protest was to be determined by the Imperial Chancellor.

Interest was not to be allowed with respect to such extensions. Decree of Jan. 18, 1915, Reichsgesetzblatt, 1915, p. 23; 3 Kriegsnotgesetze, 136.

Reichsgesetzblatt, I914, p. 387; I Kriegsnotgesetze, 126; 76 Goldschmidt, 509.

su Reichsgesetzblatt, I914, p. 399; I Kriegsnotgesetze, I39; 76 Goldschmidt, 5 II.

${ }^{*}$ Reichsgesetzblatt, I914, p. 413; I Kriegsnotgesetze, 16x; 76 Goldschmidt, 5I5.

$\approx$ Reichsgesetzblatt, 1914; p. 449; 2 Kriegsnotgesetze, 69; 76 Goldschmidt, 525.

"Reichsgesetzblatt, 1914, p. 482; 2 Kriegsnotgesetze, 70.

* Reichsgesetzblatt, I914, p. 519; 3 Kriegsnotgesetze, 4I; 77 Goldschmidt, I20.

- Reichsgesetzblatt, 1915, p. 32; 3 Kriegsnotgesetze, 156.

' Reichsgesetablatt, I915, p. 129; 4 Kriegsnotgesetze, 164. 
In the new decree it was provided that all periods should expire on May 3I, I9I5, except so far as a later time should appear from other provisions.

A decree of May I7, I9I $5{ }^{91}$ modified the decree of Mar. 4 , I9I5, with respect to Alsace-Lorraine and certain portions of East Prussia so as to make the period terminate at the earliest on July 3 I, I9I 5 . The time was extended to Oct. 30 , I9I 5 , by a decree of July 22 , I9I $5,{ }^{\text {,2 }}$ and to Jan. 3I, I9I6, by a decree of Oct. 2I, I9I $5 .^{93}$ By a decree of Jan. 6, I916, the time was extended for Alsace-Lorraine until May I, I9I $6 ;^{94}$ for the other parts it was not extended. ${ }^{95}$

Italy. By a decree of Aug. 4, I9I $4{ }^{p e}$ the maturity (scadenza) of bills and notes payable in Italy between Aug. I and Aug. 20, inclusive, was postponed twenty days. A decree of Aug. I6, I9I4, ${ }^{97}$ extended the time for payment with respect to the above instruments and with respect to those falling due before Sept. 30, I9r4, forty days in the option of the debtor, provided the latter paid not less than $15 \%$ of their amount at maturity and $6 \%$ interest for the extended time. Instruments issued on Aug. 4 or later, falling due before Sept. 30, were not to have the benefit of this extension, unless they were being renewed. The time for protesting was extended to the fourth business day after the day of maturity. The decree provided expressly that the drawer and the indorsers were to have the benefit of such extensions upon the same terms as the principal debtor.

According to a decree of Sept. 27, r $914,{ }^{98}$ all bills and notes issued before Aug. 4, I9I4, and falling. due in the months of October, November and December, I9I4, whether extended by the decree of Aug. I6, or falling due for the first time, were given a moratorium of three months, two months and one month, respectively, provided that $20 \%$ of the original amount was paid at maturity and subsequently for each month. Six per cent interest was to be paid for all extensions.

The decree of Dec. 20 , $19144^{99}$ provided for a final extension in the option of the debtor with respect to instruments issued before Aug. 4, I9I4, which had been postponed until Jan., I9I5, by the decree of Sept. 27. If the original maturity was from Sept. 22 to Sept. 30 or from Oct. I to Oct. 3I, twenty days were allowed. Forty days were allowed if the original date of maturity was from Nov. I to Nov. 30 , I9I4, and sixty days, if it was from Dec. I to Dec. 3I, I9I4. No

${ }^{27}$ Reichsgesetzblatt, 1915, p. 284; 6 Kriegsnotgesetze, 39; 77 Goldschmidt, 489.

Reichsgesetzblatt, I9r5, p. 450;8 Kriegsnotgesetze, 92; 78 Goldschmidt, I35.

Reichsgesetzblatt, I9r5, p. 677; II Kriegsnotgesetze, 67; 78 Goldschmidt, 468.

Reichsgesetzblatt, I916, p. 2 (cited in 77 Goldschmidt, 468, note).

${ }^{*} 77$ Goldschmidt, 468, note.

${ }^{\infty} 66$ La Legge, Supplemento legislativo, col. 458.

"66 La Legge, Supplemento legislativo, col. 500.

- 66 La Legge, Supplemento legislativo, col. 7r3.

- 66 La Legge, Supplemento legislativo, col. 9r3. 
extension was allowed with respect to instruments issued before Aug. 4, IgI4, whose initial maturity was from Aug. I to Sept. 2I, I9I4 The time for the protest was extended to the sixth business day after maturity. Interest at the rate of $6 \%$ was to be paid for the extension.

A few special provisions may also be noted. By a decree of June 27, I9I 5 , $^{100}$ Italian subjects, corporations and partnerships holding bills and notes issued or accepted or indorsed by Austro-Hungarian subjects and falling due from the publication of the decree until sixty days after the publication of peace were relieved from the duty of protesting as evidence of nonpayment and for the exercise of recourse.

A decree of Aug. 27, I9I6, ${ }^{101}$ extended for one month the time of payment of bills and notes payable by persons residing in the districts of Pesaro and Rimini from Aug. 12, 1916, and Sept. 15, 1916. Legal interest was to be paid.

A decree of May 6, I91 $7,{ }^{102}$ extended for one month the time of payment of bills and notes payable by persons residing in the districts of Anghiari, Citerna, Città de Castello, Monterchi, Monte Santa Maria Tiberina and San Sepolcro and falling due from Apr. 24, I917, to May 15, I9r7.

Szritzerland. ${ }^{103}$ A law of Aug. 3, $1914,{ }^{104}$ conferred on the Federal Council full powers to take whatever measures it might deem necessary for the maintenance of the credit and the economic interests of the nation.

A decree of the Federal Council of Aug. 3, $1914,{ }^{105}$ provided that thirty days of grace should be allowed with respect to all bills and notes falling due at the end of July or later. The time for protesting was to begin to run only after the expiration of such time.

According to a decree of Aug. 2I, I9I $4,{ }^{100}$ the decree of Aug. 3 was to apply to all bills and notes which were due at the end of July or fell due during the month of August. With respect to bills and notes falling due in Sept., I9I4, the time for protesting for nonpayment was to begin to run from Oct. I, IgI4.

A decree of Aug. I7, I9I4, ${ }^{\text {I07. }}$ authorized a debtor domiciled in Switzerland to set up against a creditor domiciled abroad the same defences in regard to postponement of payment (Stundungseinreden) which a debtor domiciled in such foreign country might have by virtue

\footnotetext{
${ }^{100} 67$ La Legge, Supplemento legislativo, col. 516.

${ }^{101} 68$ La Legge, Supplemento legislativo, col. 404.

${ }^{102} 59$ Cronaca legislativa, Supplemento al Monitore dei tribunali, I917, p. 367, col. 2.

${ }^{103}$ See Appendix C.

${ }^{104}$ Amtliche Sammlung der Bundesgesetze und Verordnungen (N. S. Igr4) 347.

${ }^{105}$ Amtliche Sammlung der Bundesgesetze und Verordmungen (N. S. I9I4) 350.

${ }^{100}$ Amtliche Sammlung der Bundesgesetze und Verordnungen (N. S. I9I4) 397.

${ }^{10 \pi}$ Amtliche Sammlung der Bundesgesetze und Verordnungen (N. S. I9I4) 389.
} 
of his domiciliary law with respect to a creditor who was domiciled in Switzerland.

This decree was revoked from the beginning and replaced by a decree of Dec. 4, $1914,{ }^{108}$ which granted to debtors domiciled in Switzerland against creditors domiciled elsewhere the same defences, both substantive and procedural, which a debtor domiciled in such foreign country possessed according to the war legislation of such country against a creditor who was domiciled in Switzerlarid. The same rule was applied in favor of debtors domiciled in Switzerland with respect to creditors domiciled in Switzerland who had obtained their claim through assignment from a creditor domiciled in a foreign country.

\section{French moratory legislation of $x 870-7 I$}

On Aug. 13, I870, a law was passed which provided as follows : ${ }^{109}$

"Art. I. The time within which protest and all other acts necessary for the preservation of recourse, with respect to bills and notes (valeur negociable) issued before the promulgation of the present law must be made, is extended (prorogé) one month.

"Reimbursement cannot be demanded from the indorsers and other parties liable during such time.

"Interest shall be due from maturity until payment."

The time was extended thirty days by the Government of National Defense by a decree of Sept. I0.110 This extension was to apply to instruments issued after the passage of the law of Aug. 13. During the investment of Paris (Sept. I8, I870, to Jan. 28, I871) other extensions of one month each were granted by decrees of Oct. II, ${ }^{111}$ Nov. Io, ${ }^{112}$ Dec. $12,{ }^{113}$ and Jan. 12, 1871.114 By the decree of Jan. 27 , $187 x, 115$ the period was extended to Feb. I3, I87x, inclusive.

The Delegation Government of National Defense, at Tours and Bordeaux, issued several decrees, - on Oct. 3 , I870, ${ }^{116}$ Nov. 5 , I870, ${ }^{117}$ Nov. $14,1870,{ }^{118}$ Dec. 9, $1870,{ }^{119}$ and Jan. 8, 1871. ${ }^{120}$ The decree of Oct: 3 provided that the extensions granted by the law of Aug. I3, I87o, and by the decree of Sept. Io should not apply to instruments issued since Oct. 14,1870 . The substance of the decree of Nov. 5 was as follows:

x. Bills and notes embraced within the law of Aug. I3 and the decree of Sept. Io, as well as all instruments issued since that date,

${ }^{108}$ Amtliche Sammlung der Buindesgesetze und Verordmungen (N. S. I914) 595.

${ }^{109}$ Duvergier, Collection complete des lois, decrets, etc. 1870, p. 285.

${ }^{210}$ Duvergier, 326.

${ }^{111}$ Duvergier, 346.

112 Duvergier, 360.

${ }^{113}$ Duvergier, 372.

116 Duvergier, I87I, p. 4.

${ }^{115}$ Duvergier, I87I, p. 13.

${ }^{118}$ Duvergier, 1870, p. 392.

${ }^{117}$ Duvergier, 437.

${ }^{118}$ Duvergier, 452.

${ }^{118}$ Duvergier, 479.

${ }^{120}$ Duvergier, I87I, p. 27. 
should be subject to protest, etc., within the times specified by the commercial code.

2. All instruments of whatever date of issue, since Aug. I5, should not be demandable until ninety days after the date of their maturity. (The object of this provision was to fix the time at which the payment of instruments issued up to (jusqu'a) Oct. I5, 1870, might be demanded, and to determine the interpretation of the preceding legislation and decrees on the subject.)

3. The protest might be made during five days from the day that payment could be demanded.

4. Until the end of the war and for one month thereafter the judges should have authority to give the defendant time to pay.

5. The above provisions should not apply to the invaded districts. In these departments the maturity was extended ipso jure and all protests and suits were prohibited.

The decree of Nov. I4 provided (art. I) that until the following Dec. I5, no protests should be made nor suits instituted with reference to instruments issued before Aug. I5.

The decree of Dec. 9, 1870 , extended the time granted by the decree of Nov. I4 until Jan. I5, I87I.

The decree of Jan. 8 was intended to remove uncertainties in the interpretation of the above law and decrees and provided as follows:

I. The maturity (l'échéance) of instruments issued before Aug. I5, I870, should be extended five months. Those issued after Aug. I5 and up to (jusqu'à) Oct. I4, I870, should be extended three months. If the maturity thus postponed three months was before Jan. I5, it should nevertheless be extended to Jan. I5. In the latter event the maturity should be postponed to Jan. I5. The instruments issued since Oct. I4 should be governed by the provisions of the commercial code.

2. Until Apr. I5, the time for protesting should be ten days.

3. No suit should be brought until the end of the war against parties liable upon bills and notes issued before Aug. 15, I87o, although protest had been made.

4. The provisions of the decree of Nov. 5, 1870, relating to departments that were invaded, should continue to govern. All provisions inconsistent with the present decree were repealed.

The following laws and decrees were made after the investment of Paris had ceased. On Feb. 9, I87I, ${ }^{121}$ the Government of National Defense extended the time for protesting granted by the law of Aug. I3 and the various decrees including that of Jan. 27, I87x, one month from Feb. 13, I87I. Interest was to remain payable from the time of maturity. The other provisions of the law of Aug. I3 were reaffirmed. All inconsistent decrees were revoked.

\footnotetext{
${ }^{121}$ Duvergier, 16.
} 
The National Assembly passed four laws relating to our subject. The first was of Mar. Io, I87x, and contained the following provisions : ${ }^{\mathbf{1 2 2}}$

I. Bills and notes issued before or subsequent to the law of Aug. I3, x870, and due after Apr. I2, I87I, should enjoy no further extension and should be demandable in accordance with the ordinary rules of law.

Bills and notes falling due between Aug. I3 and Nov. I2, I87o, should be demandable seven months after the date of original maturity, with interest from the latter date.

Bills and notes due between Nov. I3, I870, and Apr. I2, I87I, should be demandable on the corresponding day between June ${ }_{3} 3$ and July I2 with interest since the date of original maturity. Instruments issued later than Feb. 9 should not be extended.

2. The time granted for protesting should be ten days.

3. The failure of holders of bills of exchange payable at sight or after sight to present such instruments for acceptance or payment after Aug. 13, 1870, should be excused provided such presentment was made within a certain fixed time after the promulgation of the present law.

4. In the departments occupied by foreign troops the commercial courts might during the year I87r give reasonable extensions of time to debtors within which to pay.

Through the law of Mar. 24, $187 \mathrm{x}, 123$ bills and notes within the terms of the law of Mar. Io and falling due between Mar. ${ }_{3} 3$ and 24 were extended to Apr. 24, and those falling due between Mar. 25 and Apr. 24 were extended one month. The commercial court of the Seine was also authorized to grant during the year $187 \mathrm{I}$ reasonable extensions of time for payment.

The law of Apr. 26, $187 \mathrm{r},{ }^{124}$ provided that bills and notes payable in the department of the Seine which fell due after Mar. 18, 187r, and until ten days after the reesstablishment of the postal service between Paris and the other parts of France should not be demandable until after such time. It also gave all holders falling within the terms of this law ten days within which to protest. The courts were authorized to give extensions only with respect to persons signing, indorsing or accepting who lived in the department of the Seine or in the invaded departments mentioned in art. 3 of the Treaty of Feb. 26, 1871 .

The law of July $4,1871,{ }^{125}$ extended the periods granted by the law of Mar. Io four months. These provisions were not to apply, however, to instruments payable in the department of the Seine or in the

\begin{tabular}{|c|c|}
\hline $\begin{array}{l}122 \text { Duvergier, } 57 . \\
\text { Duvergier, } 6 r .\end{array}$ & $\begin{array}{l}124 \text { Duvergier, I03. } \\
{ }^{223} \text { Duvergier, 126. }\end{array}$ \\
\hline
\end{tabular}


district of Sèvres, Meudon and Saint-Cloud (Seine-et-Oise) and issued before May 3I, I87I. According to this law instruments issued since May $3^{\mathrm{I}}$ and falling due before the promulgation of the present law must be protested within five days from such promulgation. Within twenty days after the promulgation holders of bills and notes whose original maturity was before such promulgation must notify their debtors of the amounts due. A like notice was to be given within five days with respect to instruments falling due after the promulgation of the present law. In case of failure to give such notice the holder was to lose his interest from July I5, I871. The debtor was to have as many days of grace as were granted by the present law to the holder for the protest. All acts required for the preservation of recourse with respect to instruments that were protested either before or after the law of Aug. I3, I870, might be done within twenty days after the promulgation of the present law. The failure of holders of instruments payable at sight or after sight to present them for acceptance or payment since Aug. I3 was excused provided such presentment was made within a certain time after the promulgation of the present law. The commercial court of the Seine was authorized to grant debtors during the year I87I moderate extensions of time within which to pay.

\section{Analysis of. French legislation}

The outline of the French legislation of 1870-7I relating to bills and notes above given shows that such legislation contained various elements, the principal ones of which are the following: ${ }^{126}$

I. The great bulk of the legislation purported to extend the time for payment. It did so generally in the form of postponing the time for protesting. A few of the laws or decrees spoke directly of the postponement of the maturity. ${ }^{127}$

2. Several decrees provided, in addition to such postponement of the time of payment, a few additional day's, from five to ten in number, for the benefit of the holder during which he might protest the instrument. ${ }^{128}$

\footnotetext{
${ }^{120}$ For a full analysis see Fick, Ueber internationales Wechselrecht in Beziehung auf Fristbestimmungen, insbesondere die französischen Wechsel-Moratoriumsgesetze und Dekrete. The work originally appeared in the form of articles in the Centraiorgan für das deutsche Handels- und Wechselsrecht, vol. 7, 167-182; vol. 8, pp. I29-2I4.

${ }^{20}$ The decree of Jan. 8, 1871, spoke of the postponement of "maturity," and the laws of Apr. 26 and July 4, 1871, designated the legislation as "a law for the postponement of the maturity of negotiable instruments."

${ }^{128}$ See decrees of Nov. 5, 1870, and of Jan. 8, I87x, and the laws of Mar. Io, I87x, and of July 4, I87r. The laws of Mar. Io, I87r, and of July 4, I87r, also extended the time within which bills of exchange payable at sight or after sight might be presented.
} 
3. Protests were prohibited expressly for a period of time with respect to certain instruments. ${ }^{129}$

4. A number of the laws and decrees authorized the courts to grant the debtor additional time for payment. ${ }^{130}$

5. According to the law of July 4, r87I, all acts necessary for the preservation of recourse with respect to instruments protested before the law of Aug. I3, I87o, or subsequently, might be made within twenty days after the promulgation of this law. This would authorize the holder to cite the defendant into court after the expiration of the ordinary period of two weeks prescribed by French law.

\section{APPENDIX B}

RECOGNITION OF MORATORY LEGISLATION ENACTED BY A FOREIGN STATE

\section{Decisions in various countries}

So far as the recognition of foreign moratory legislation relating to bills and notes has come before the courts it has been almost uniformly sustained. A contrary view has been taken by the Supreme Commercial Court of Leipsic and by the Commercial Court of Zurich. In the following cases the French legislation of 1870-1871 was sustained with respect to drawers or indorsers who had entered into their respective contracts in the jurisdiction where the court was sitting.

Austria. The Supreme Court of Austria passed on the .question in a decision of May 28, $1872,{ }^{1}$ and again on June $13,1872 .{ }^{2}$ The court took the view that the French legislation merely extended the time for protesting which, in conformity with art. $86^{3}$ of the Austrian Bills of Exchange Law, was controlled by the law of the place where the bill was payable. The same view had been expressed by the court in an advisory opinion which it had rendered a year earlier, namely on May 3I, I87I, at the request of the Austrian Minister of Justice. ${ }^{4}$ The court admitted, however, that the distinction between legislation postponing the day of protest and legislation postponing the time of payment was very questionable. Even if the protesting of bills was not

${ }^{120}$ See decree of Nov. I4, 1870.

${ }^{150}$ See decree of Nov. 5, 1870, and laws of Mar. 10, 1871, Mar. 24, I871, Apr. 26 , I87r, and July $4, \mathrm{I} 87 \mathrm{I}$.

${ }^{1}$ Krall, Sammlung von wechselrechtlichen Entscheidungen des österreichischen obersten Gerichtshofes, nos. 214, 215; 27 Seuffert's Archiv, no. 168. An abstract of the case is given in I8 Goldschmidt, 637.

${ }^{2}$ Krall, no. 216 .

'Art. 86 of the Austrian Bills of Exchange Law, which is identical with the German law, reads as follows: "The form of the acts required to be done at a foreign place for the exercise or preservation of the right of recourse with respect to bills of exchange is governed by the law of such place."

I8 Goldschmidt, 638. 
prohibited by the French legislation during the extension 'granted, no suit could be brought under it against prior parties. To hold that the foreign drawer or indorser might be held before the drawee or acceptor was under a duty to pay would lead to inextricable difficulties.

The Austro-Hungarian Consular Court at Constantinople sustained the French legislation with respect to an Austro-Hungarian drawer in a decision of Apr. I5, I872..$^{5}$ The court based its conclusion in part upon art. 86 of the Austrian Bills of Exchange Act and also on the more general grounds of equity and reciprocity. It assumed that under the French legislation it was impossible for the holder to make the protest within the time specified by Austrian law.

Belgium. The question came before the Court of Appeals of Brussels on Apr. 22, 1872, ${ }^{\circ}$ and before the Court of Ghent on May I5, 1873. ${ }^{7}$ In the former case a note payable in Paris on Sept. 28, I870, had been indorsed by the defendant, a Belgian subject. It was not certain whether the defendant had indorsed the note in France or in Belgium. The note was protested for nonpayment on Aug. 30, I87I. Judgment was rendered against the defendant. The court seems to assume in the first place that the indorser agreed to pay in Paris and that the law of the place of payment governed his liability. But even if Belgian law was applicable the court concluded that the French moratory legislation made it not only legally but also actually impossible to protest the note during the time that such legislation was in effect, and that the existence of such a state of vis major operated to excuse the delay under the Belgian law of bills and notes:

The court of Ghent reached the same conclusion upon the same ground.

England. The effectiveness of the French moratory legislation was recognized with respect to English drawers and indorsers in the case of Rouquette $v$. Overmann. ${ }^{8}$ The bills in question were payable on Oct. 5, I870, and were accepted by the French drawee. They were presented for payment on Sept. 5, I87x, the date to which the time of presentment and protest had been extended by the French law, and were protested for nonpayment on Sept. 6. The Court of Queen's Bench held that the legislation was clearly binding on the acceptor and that no action could have been brought against him in England before Sept. 5. The fact that the legislation was ex post facto and interfered with vested rights was deemed immaterial, at all events so far as the obligation of the acceptor was concerned. The same conclusion

\footnotetext{
'I Clunet, Journal de droit international prive, roo. An abstract of the case may be found in 2r Goldschmidt, 582 .

- Pasicrisie belge, 1872, 2, 157; I Clunet, 209; 7 Annali, I, 49, notè. An abstract of the case is given in 21 Goldschmidt, $58 \mathrm{I}$.

'I Clunet, 2r3.

(1875) L. R. 10 Q. B. 525, 44 L. J. Q. B. 22 I.
} 
was reached with respect to the drawer and indorser. Their contracts were regarded as contracts of suretyship which called for performance in France. As regards presentment for payment and protest for nonpayment, the law of the place where the bill was payable was therefore deemed to control. Any other doctrine would lead to very startling anomalies. The form in which the legislation was expressedwhether it added merely days of grace or extended the time for protesting or the maturity-was in the opinion of the court of no importance.

The English Supreme Consular Court at Constantinople rendered a decision to the same effect on June I3, I872, in the case of Allatini $\&$ Co. v. Abbott. ${ }^{\circ}$ In this case two bills of exchange had been drawn in Saloniki on a drawee in Genoa which were payable at Marseilles on Dec. 20, 187o. The bills were payable to the defendant and had been indorsed by him to the plaintiffs. The bills were presented for payment on June $20,187 \mathrm{I}$, in accordance with the French legislation, and were dishonored. The court, relying on the authority of Hirschfield v. Smith, ${ }^{10}$ held that the French law governed even as regards foreign indorsers. Replying to the argument that if the French legislation could extend the time for payment for eleven months it could do so for five or fifty years, the learned court said:

"The rule of comity must be qualified so that the established and fair principle of a contract should not be violated. . . Under the exceptional state in which France found herself it was not inequitable, and it would have been more injurious to citizens of other countries if a universal repudiation or bankruptcy had taken place in commerce instead of the time for meeting contracts being extended."11

France. The Court of Appeals of Aix held in a decision of Apr. 9, I872, that the French legislation was binding upon foreign drawers and indorsers. ${ }^{12}$ No particular grounds for the decision were given.

Italy. Some of the lower Italian courts were inclined at first to hold that the French moratory legislation was not binding with respect to Italian drawers and indorsers. Such a conclusion was also reached by the Court of Appeal of Genoa on June 27, $187 x_{1}^{13}$ but this decision was reversed by the Court of Cassation of Turin in a decision rendered Mar. 6, I872. ${ }^{14}$ The bill of exchange involved in the case had been drawn in Italy on July 18 , I870, on a drawee at Nice, France, and was payable thirty days after date. It appears to have been presented

26 L. T. Rep. N. S. 746.

${ }^{10}$ L. R. I C. P. $347 . \quad{ }^{12}$ D. $1872,2,202$.

${ }^{11} 26$ L. T. Rep. N. S. 746, 748. $\quad{ }^{13}$ Monitore, 187x, p. 918.

"Annali, 1872, I, I07; Monitore, I872, p. 234; Dalloz, 1872, II, p. x; Sirey, $1872,2,217$ and note by Lyon-Caen. An abstract of the case may be found in I8 Goldschmidt, 633 . 
for payment at its maturity but payment was refused. Protest for nonacceptance and nonpayment was made on Dec. 8, I87o. The Court of Cassation held the Italian indorser liable. In its opinion the learned court admitted that the lex loci contractus, that is, Italian law, governed the contract of the Italian indorser in general, but held that by virtue of the rule locus regit actum there is a legal presumption that the drawer and indorser submitted to the law of the place where the instrument was payable with respect to the time and mode of presentment and protest. Although the French legislation did not prohibit the protesting of bills in express terms it did so by implication. The question whether the obstacle in the way of timely presentment and protest was of a legal or of an actual character was deemed immaterial. The legislation itself was deemed to be proof of the actual existence of a condition of vis major and impossibilium mulla est obligatio. Italy could not well object to such legislation inasmuch as it had enacted similar laws at various times. Since the obligation of the drawer and indorser is secondary, no action would lie against them until it could be legally ascertained that the principal debtor had not paid and under the French legislation the drawee or acceptor was not bound to pay until the expiration of the extension granted.

Decisions to the same effect were rendered by the same court on July $30,1873,{ }^{15}$ and on May 20, $1879 .{ }^{16}$ In the former, which reversed the decision of the Court of Appeals of Milan of Apr. 16, 1872, ${ }^{17}$ the court assumed that the protesting of bills during the time covered by the moratory legislation was unlawful. In the second case the court emphasized the fact that the moratory legislation created a legal obstacle, and that the siege of Paris constituted an actual obstacle, both of which would excuse the delay in the presentment and protest under the Italian law of bills and notes.

The question was decided in the same manner by the Court of Cassation of Florence on June $16,1873 .{ }^{18}$ The court reached the conclusion on the following arguments:

(I) As regards form, mode, and time of protest all parties must be deemed to have submitted to the law where the instrument is payable:

(2) Where the holder has used due diligence but is prevented by a condition of vis major from presenting and protesting the instrument, any delay caused thereby will be excused.

(3) Art. 2 of the French law of Aug. 13, I87o, providing that no suit shall be brought, prohibits impliedly the protesting of bills. A protest was therefore legally impossible. And it must be presumed

${ }^{15}$ Monitore, 1873, p. 893.

${ }^{10}$ Annali, 1879, I, 405; Monitore, 1879, 636;8 Clunet, 543. The case affirmed the decision of App. Rome, of June 12, 1872, Annali, 1872, 2, 266.

${ }^{17}$ Monitore, 1872, p. 391 .

${ }^{18}$ Annali, I873, I, 47. 
that no public official could be found who would protest a bill in violation of law.

(4) The liability of the drawer and indorser is secondary and will not arise until the refusal of the drawee or acceptor to pay can be proved by a proper protest. $^{19}$

Norway. The Supreme Court of Norway recognized the French legislation with reference to a Norwegian indorser in a decision of Jan. I6, 1875.20 The bill had been drawn on July 6,1870 , in Norway upon Rouen and was payable in Paris three months after date. Protest for nonpayment was made on Sept. 8, I87I. Delay in presentment and protest was excused because, in the opinion of the court, such protest could not be made during the time of the French moratory legislation, and the existence of vis major constituted a defense under the Norwegian law of bills and notes.

Sweden. The following case came before the Supreme Court of Sweden in $1873 .{ }^{21}$ A bill was drawn in Stockholm on a drawee at Rouen and was payable in Paris three months after date. The bill was duly executed by the drawee and was presented for payment on Aug. I7, I87I, in conformity with the French legislation, and protest was made on Aug. I8. The court of first instance held ${ }^{22}$ that the drawer's contract was governed by Swedish law and that even if the French legislation were to be interpreted as making presentment and protest impossible it could not affect the obligation of such foreign drawer, especially since such legislation was enacted subsequent to the issue of the instrument. As the bill was not presented on Sept. r7, I870, and protested at that time, the defendant was discharged. The Court of Appeal of $\mathrm{Svea}^{23}$ affirmed the decision on Apr. 25, I872. The Supreme Court, however, by a decision of 4 to 3 reversed the judgment, basing its decision upon sec. 30 of the Swedish law of bills of exchange of 185 r.

Switzerland. The Court of Appeal of Geneva dealt with the question in a decision of Mar. 25, $1872 .{ }^{24}$ The bill in question was drawn on June 4, I87o, in Prussia on a drawee in Paris and was payable three months after date. It was indorsed by the defendant to plaintiff in Geneva and was protested for nonpayment on Aug. 5, I87I. The

\footnotetext{
${ }^{10}$ The Court of Appeal of Milan, in a decision of Apr. 4, 1873, allowed execution on a French judgment against an Italian indorser which was based upon the French moratory legislation. See I Clunet, I38.

${ }^{20}$ An abstract of the case is given in 2I Goldschmidt, 580 .

${ }^{21}$ Decision of May 14, 1873. I Clunet, 149.

$\approx$ I Clunet, I5I.

${ }^{23}$ I Clunet, I52.

"Journal de Genève, Apr. 10, 1872, no. 84; Sirey, I872, 2, 217; Belgique judiciaire, 1872, col. 524; 7 Amali, 1,47 , note. An abstract of the case is given in 21 Goldschmidt, $58 \mathrm{r}$.
} 
court held that the question of timely presentment and protest related to the form of acts and was therefore subject to the law of the place where such acts were to be done. The contracts of the drawer and indorsers were regarded by the court as contracts of suretyship and as governed therefore by the law controlling the principal obligation, namely, the law of the place where the bill was payable. The parties must be deemed to have submitted to this law. The court held that according to the law of Geneva an unavoidable delay in presentment or protest was excusable on the ground of vis major and that instead of leaving the matter to the courts a legislator might determine the existence of a condition of vis major.

Recognition to the French moratory legislation with respect to local drawers and indorsers was denied, on the other hand, by the Supreme Commercial Court of Leipsic and the Commercial Court of Zurich.

Germany. The leading case on the subject in Germany is the decision by the Supreme Commercial Court of the German Confederation, of Feb. 21, 187 . $^{25}$ In this case suit was brought against the German drawer of a bill of exchange which had been accepted and was payable in Paris on Aug. 20, 1870. The bill was presented for payment on the day of its maturity but was not protested. The court held that the liability of the drawer had not been fixed. With respect to art. 86 of the German Bills of Exchange Law it took a different view from that expressed by the highest court of Austria. In its opinion this article did not require the recognition of the French legislation with respect to German drawers and indorsers. The court admitted that the expression "form" used in art. 86 was not to be understood in a strict sense but would include days of grace and the like. The question whether the law of the place where the instrument was payable could control the matter of days of grace introduced or extended subsequent to the issue of the instrument was not decided, for the court reached the conclusion that the French legislation did not involve the creation of days of grace nor a mere extension of the time for protesting. It contained nothing less than a postponement of the day of payment (Zahlungstag). This day was regarded, however, as fixed by the bill itself, the terms of which cannot be changed without the assent of the party in question. Such party cannot be deemed to have submitted in this respect to the law where the instrument is payable.

The contention that the French legislation had created a situation of vis major was met by the court with the statement that no such defense was recognized under the German law of bills and notes, which governed the contract of the German drawer and indorser.

\footnotetext{
${ }^{2}$ I R O H G, 286; I Clunet, I85; Dalloz, I872, II, p. I, note. An abstract of the case may be found in 18 Goldschmidt, 628 .
} 
The above decision was followed by the court in a subsequent decision. ${ }^{2 B}$ Two decisions of the Commercial Court of Hamburg ${ }^{2 T}$ and a decision of the Obergericht of $\mathrm{Mainz}^{28}$ reached the same result. A similar view was taken in 1872 by the Appellate Court of Colmar, ${ }^{20}$ which had recently been created for Alsace-Lorraine, the court holding that even in territories following the French system of bills and notes the defense of vis major was not recognized.

Szitzerland. One of the strongest decisions on the subject was rendered by the Commercial Court of Zurich on May 22, $1871 . .^{30}$ In this case the bill was drawn on June 22, I870, on a drawee in Marseilles and was payable three months after date. The bill was accepted by the drawee and was indorsed by the defendant to the plaintiff in Zurich on July I8, I87o. The bill was presented for payment on Mar. I, I87I, and protested for nonpayment. The acceptor of the bill had become insolvent and notice of this fact had been given to the defendant in Aug., I87o. The court held with respect to the question whether timely protest had been made, that it was governed as regards all parties by the law of the place of payment of the bill existing at the time of maturity. The fact that a change in the law had been made subsequent to the execution of the instrument was of no importance as the holder had no vested rights. The law of the place of payment has no authority, however, to change the maturity of the instrument as regards foreign drawers and indorsers whose contract is governed by the lex loci contractus. The fact that the omission to protest resulted from a condition of vis major was of no consequence since such a defense was not recognized under the law of Zurich, where the contract was made. The French legislation had in fact changed the maturity of the bill and had not merely extended the time for protesting nor introduced mere days of grace.

${ }^{20} 5 \mathrm{R} O \mathrm{H} \mathrm{G}$, IOI (decision of Feb. 9, 1872). In a decision by the same court rendered May 30, 1873 , the validity of the French legislation was sustained with respect to a German (?) subject who had executed two promissory notes in Paris and had subsequently removed his residence to Saxony, 18 Goldschmidt, 629.

In a decision of Sept. 13, I873, it was held by the same court that the French legislation constituted a case of vis major which excused delay in protest under the French law. The place where the defendant indorsed the bill did not appear but it must have been in France. The court expressly stated that its decision of Feb. 2r, I87r, did not apply to the facts in the case. II $\mathrm{R} \mathrm{O} \mathrm{H} \mathrm{G,} 74$.

${ }^{27}$ Hamburgische Handelsgerichtszeitung, I871, no. II6, p. I7I; ibid. no. I30, p. 204.

${ }^{\$}$ This decision was not printed but is given in I8 Goldschmidt, 64x.

${ }^{20} 3$ Zeitschrift fiir französisches Civilrecht, 148 . An abstract of the case is given in 18 Goldschmidt, 640.

${ }^{30} 22$ Zeitschrift fïr Kunde und Fortbildung der aïrcherischen Rechtspflege, $37 \mathrm{I}$. A summary of the case may be found in I7 Goldschmidt, 3or. 


\section{Juristic opinion}

The French moratory legislation of I870-187I and the decisions of the various courts with respect thereto have given rise to much discussion in the different countries. The following represents a brief summary of the juristic opinion on the subject, according to countries.

Austria. Juristic opinion has been divided. The view reached by the highest Austrian court on the subject mentioned in the text, namely, that the French legislation should be recognized as binding with respect to Austrian drawers and indorsers, was also reached by a committee of the Bar Association of Lower Austria by a vote of 6 to 5, and likewise by Götze and Swoboda. The majority of the committee of the Bar Association were of the opinion that the date of maturity had not been changed by the French legislation and that art. 86 of the Austrian Bills of Exchange Law was therefore applicable. They also contended that a distinction should be drawn between ordinary vis major. and moratory legislation, and that the latter should be recognized although the defense of vis major does not exist under the Austrian law of bills and notes. ${ }^{31}$ Swoboda ${ }^{32}$ expressed the same view. In his opinion, art. 86 was applicable not only to the mode and time of protesting but also to the necessity of protesting. The real nature of the French legislation consisted in a change in the existing French law regarding the form of the steps necessary for recourse.

The principal argument advanced by Götze ${ }^{33}$ was to the effect that inasmuch as no action could be brought against the party primarily liable, except in accordance with the provisions of the French legislation, such legislation must be binding also upon the foreign drawer and indorser.

A most thorough treatment of the subject is to be found in the articles by Jacques, ${ }^{34}$ who disagrees with the conclusion of the Austrian Supreme Court, and accepts the view of the Supreme Commercial Court of the German Confederation. He reached the conclusion that the French legislation had in fact changed the maturity of bills and notes, however much the actual intent may have been disguised, and that art. 86 of the Austrian Bills of Exchange Law therefore did not apply.

Belgium. The distinguished Belgian jurist, Rolin-Jaequemyns, was of the opinion that the French legislation extended the time of payment and that the decree of the Supreme Commercial Court of the German Confederation was therefore correct. Even with respect

\footnotetext{
${ }^{31}$ Wochenschrift fïr deutsches Handels- und Wechselrecht nach den Entscheidungen des Oberhandelsgerichts, $187 \mathrm{I}$, no. 22, p. I70.

${ }^{32}$. Allgemeine österreichische Gerichtszeitung, I871, pp. 298, 301.

${ }^{33}$ Ibid. 165.

${ }^{34}$ Ibid. 410 .

${ }^{35} 3$ Revue international de droit comparé, 504.
} 
to countries governed by French law he would hold that the rule impossibilium nulla est obligatio had no application to the case.

Rolin ${ }^{36}$ has expressed the view that protest was impossible under the French legislation and that a state of vis major was thus created which would excuse the delay in all countries recognizing that defense.

France. The French legislation has been sustained by most French jurists even as regards foreign drawers and indorsers, either on the ground that the legislation postponed only the time for protesting and not the maturity of the instrument, ${ }^{37}$ or on the ground that as to the holder it constituted a case of vis major which would excuse any delay in the presentment and protest authorized by the legislature.s8

Chrétien ${ }^{39}$ holds the view that only the protest was prohibited under the French legislation and not the presentment. The holder should therefore have presented the instrument, according to this writer, at the time of original maturity. Upon a failure to pay upon such presentment immediate recourse might be taken, the failure to protest being excused on the ground of vis major.

Germany. Practically all of the jurists agree with the decision of the Supreme Commercial Court of Leipsic that the French legislation contained a postponement of the time of maturity, that art. 86 of the German Bills of Exchange Law was not applicable to such a case, and that the legislation could not be recognized on the ground of vis major. ${ }^{40}$ The minority view is represented by Salpius and Ladenburg. The former ${ }^{41}$ maintains that the necessity of protest belongs to the formalities which are subject to the law of the place of payment. This writer concludes that in view of the French legislation which made the protest impossible, an immediate right of recourse should have been allowed abroad without the necessity of producing a protest. Ladenburg ${ }^{42}$ takes the view, however, that notwithstanding the intention of the French legislator to extend the time for payment, the wording of the legislation actually extended only the time for protesting. Applying the analogy of days of grace and the rule relating to holidays, he concluded that art. 86 of the German Bills of Exchange Law applied, which submits the matter to the law of the place of payment.

Holland. Of the Dutch jurists who have dealt with the question

\footnotetext{
${ }^{36} 2$ Rolin, 553-554.

${ }^{37}$ Despagnet (5th ed. by de Boeck) 997-998; Lyon-Caen, Belgique judiciaire, 1873, col. 569; 4 Weiss (2d ed.) 466.

${ }^{38} 4$ Lyon-Caen \& Renault, no. 663; 3 Champcommunal, Annales, I894, II, 250.

${ }^{\circ}$ Etude sar la lettre de change, 198.

${ }^{20} \mathrm{Bar}, 683$; Keysser, 17 Goldschmidt, 198. This is also Goldschmidt's view. I7 Goldschmidt, 294; I8 ibid. 625.

"Ig Goldschmidt, 6, 58 .

7 Centralorgan für das deutsche Handels- und Wechselrecht, N. S. 288, 290-292.
} 
specially, Van Raalte would recognize the French legislation with respect to foreign drawers and indorsers, while Hovy and Kist would not do so. Van Raalte ${ }^{43}$ reached the conclusion on the ground that the French legislation, whether it intended to do so or not, had actually resulted in the creation of days of grace. The circumstance that the time of grace for protesting amounted in the aggregate to eleven months and that it was granted subsequent to the creation of a particular instrument was deemed by him of no consequence.

Hovy $^{44}$ and Kist ${ }^{45}$ agreed with the Supreme Commercial Court of Leipsic that the time of maturity had been postponed. Hovy took the view that the protesting of the instrument was not prohibited by the French moratory legislation and that no defense of vis major therefore existed.

$\mathrm{Jitta}^{46}$ refers to the question in his work, La substance des obligations dans le droit international privé. According to this distinguished writer, moratory legislation should be sustained on the broad ground that the foreign drawer and indorser should have foreseen as reasonable men the eventuality of such legislation being passed.

Italy. Juristic opinion has been greatly divided on the subject under consideration. Lebano ${ }^{47}$ saw in the French legislation only extraordinary days of grace. Both he and Cambon ${ }^{48}$ would recognize the legislation, however, even if it did change the day of maturity. According to Lebano the law of the place of payment governs all parties with respect to the "exigibility" of bills and notes. Vidari" expressed his opinion to the effect that the French legislation intended to extend only the time for protesting and not the maturity and that the law of the place of payment was binding upon all parties in this matter. The French legislation, according to him, constituted a case of vis major and for that reason also was a defense under the Italian law of bills and notes.

Buscemi ${ }^{50}$ attacked Vidari's view, holding that the only object of the French legislation was to relieve the French drawers and indorsers from the duty to pay. It did not extend the maturity of the instruments and did not prohibit presentment or protest. The holder was therefore under a duty to present the instrument on the day of its original maturity and to protest the same in case of nonpayment. If the protest had been prohibited, the holder should have proved presentment and nonpayment in some other way. A prohibition to protest would change the substance of the obligation of the drawer

${ }^{43}$ I7 Goldschmidt, 306.

"Magazijir van handelsregt, 1871; Mengelinen, 50.

${ }^{*}$ I8 Goldschmidt, $643 . \quad{ }^{48}$ I8 Goldschmidt, 629.

${ }^{46} 2 \mathrm{Jitta}, \mathrm{I} 40$.

"7 Archivo giuridico, 267; 9 Archivo giuridico, I88.

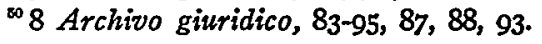


and indorser, though it was passed under the guise of affecting merely the form, inasmuch as these parties have submitted to the law of the place of payment only so far as the form of presentment and protest is concerned but not as to the necessity of these acts as a condition precedent for the preservation of recourse.

According to Guiseppe ${ }^{51}$ the effect of the French legislation was simply to abolish the requirement of a protest as a means of proving the nonpayment of bills and notes. Recourse was therefore possible without the protest upon proof of presentment and nonpayment. In his opinion the French legislation in effect changed the date of maturity and for this reason was not binding upon foreign drawers and indorsers.

A most thorough study of the subject was made by Norsa. ${ }^{52}$ This distinguished writer reached the conclusion that the French legislation had extended the day of maturity. Although he was ready to admit the existence of the defense of vis major in the Italian law of bills and notes, he concluded that the French legislation had not prohibited the protesting of bills and notes and for this reason had not created a condition of vis major.

Switzerland. Two important contributions to the subject have come from the pen of Swiss writers. One is an opinion by Munzinger and Riggeler, ${ }^{53}$ which was prepared upon the request of the Department of Commerce and Customs of the Swiss Federal Council. These authors reached the following conclusions:

(I) That the French legislation made the protesting of bills legally impossible. This would constitute a defense on the ground of vis major under the law of certain cantons but not under the law of other cantons.

(2) That the law existing at the time and place of payment would govern with respect to all parties as regards the time and mode of protesting.

(3) That the French legislation intended to extend the time for the presentment and protest as to all parties and that such legislation was binding under the rule stated under (2).

(4) In yiew of the fact, however, that the French legislation was not recognized under the German law with respect to German indorsers and the Swiss indorser was thus unable to take recourse against the German indorser, the French legislation should not be enforced against Swiss indorsers.

Professor Fick ${ }^{54}$ of the University of Zurich after a very careful

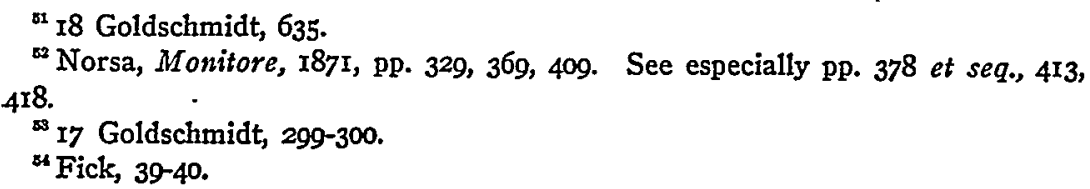


analysis of the French legislation came to the conclusion that it operated merely as an obligatory extension of the time for protesting. He admits, however, that the practical effect is very nearly the same as an extension of the maturity of the instrument. According to Fick, protest was legally impossible as long as the French moratory legislation was in force. Contrary to Munzinger and Riggeler, he regarded the law of the place of payment in force at the time the foreign drawer or indorser entered into his contract as controlling and not the legislation adopted subsequently by the law of such place. ${ }^{55}$ An indorser would be discharged, therefore, by the failure to protest the bill at the time of its original maturity if at the time he entered into the contract there was no prohibition to protest, even though such prohibition were subsequently introduced, unless the defense of vis major was recognized by the law of the place governing his contract. ${ }^{50}$ A drawer would be discharged under the same circumstances except so far as his liability might be affected under the law governing his contract by the rules relating to unjust enrichment. ${ }^{57}$ On the other hand, all parties to a bill or note who became such after the moratory legislation was enacted would be bound thereby. ${ }^{58}$

\section{APPENDIX C \\ $V$ is Major}

The term vis major is of Roman origin. Since the time of the glossators one of the most celebrated questions was whether the Roman law understood by the term vis major events which were irresistible in an absolute sense (objective theory) or whether it meant any event possessing such force that a particular individual could not under the circumstances reasonably protect himself against it (subjective theory). Until the middle of the last century the objective theory was generally recognized by the courts and jurists. ${ }^{1}$ Through the influence of Goldschmidt ${ }^{2}$ the subjective theory has come into vogue.

The term is not defined in any, of the modern codes, and means different things in different countries. ${ }^{3}$ It may have different meanings in the different codes of the same country and in the different

\footnotetext{
${ }^{85}$ Fick, 67-70. ${ }^{\circ 7}$ Fick, 56.

${ }^{60}$ Fick, 53.

${ }^{1}$ Fischer, Vis Major im Zusammenhang mit Unmöglichkeit der Leistung, 37 Jhering's Jahrbiicher fïr die Dogmatik, 210.

${ }^{2}$ Das receptum nautarum, caupomum, stabulariorum, 3 Goldschmidt's Zeitschrift, 58, 33I ; 2 Goldschmidt, Vermischte Schriften, 500.

${ }^{3}$ In Italy and France it is used to include all conditions which cannot be foreseen and guarded against in the exercise of ordinary care. Dalloz, Répertoire méthodique, Force majeure, nos. 8, 10; Cogliolo, La legislazione di guerra, I9I6, p. I00; Coviello, Del caso fortuito, 78-8I.
} 
parts of the same code. For example, Professor Endemann ${ }^{4}$ states that the term is used in an objective sense in sec. 203 of the German Civil Code and in a subjective sense in sec. 70I of the same code. Because of the uncertainty of the meaning of the term vis major, the German Bar Association at its 22d session voted that its retention by the German Civil Code would be unwise. ${ }^{5}$

The closest equivalent in Anglo-American terminology to vis major is "act of God." Vis major is, however, not identical with our term "act of God." In the law of bills and notes of many countries the doctrine of vis major operates to excuse delays in presentment and protest which are caused by insuperable obstacles. It does not go so far, however, as the Anglo-American rule which excuses delay in the presentment, protest or notice which is caused by circumstances beyond the control of the holder and not imputable to its default, misconduct or negligence. ${ }^{7}$ For example, it is questionable whether a delay caused by the sudden illness of the holder or of the notary charged with the presentment and protest will operate as an excuse under the law of all foreign countries. ${ }^{8}$ The Uniform Law of Bills and Notes adopted by the Convention of the Hague of Igra has the express provision that "matters purely personal to the holder or to the person entrusted with the presentment of the bill or with the drawing of the protest shall not be deemed to constitute cases of vis major."9

In the law of at least some of the continental countries the term vis major includes not only physical obstacles which could not be overcome in time through the exercise of reasonable diligence, but also. legal prohibitions. ${ }^{10}$

At the time of the decisions discussed in Appendix B, supra, the defense of vis major was allowed in Belgium, ${ }^{11}$ France, ${ }^{12}$ Holland, ${ }^{13}$

'Endemann, Lehrbuch des bürgerlichen Rechts (9th ed.) sec. II5.

-Verhandlungen des 22. deutschen Juristentages, I, 357, 362; IV, I2I.

- Biermann, Die höhere Gewalt im englischen und im französischen Recht; Io Archiv fïv bürgerliches Recht, 57-58.

${ }^{7}$ N. I. L., secs. 8I, II3, I47, I59; Bills of Exchange Act, secs. 46 (I), 50 (I), 39 (4), 5 I (9).

- See I Meyer, Weltwechselrecht, 93.

- Art. 53, par. 6. This convention is not yet law in any of the continental countries.

${ }^{10} 6$ Merlin, Répertoire, Fait du souverain; I Sourdat, Traité général de la. responsabilité, no. 647 .

${ }^{11}$ Namur, Lettres de change, no. I99.

${ }^{12}$ Alauzet, Commentaire de commerce (3d ed.) nos. I453-I454; 2 Bédarride, De la lettre de change, nos. 488-490; Boistel, Cours de droit commercial (4th ed.) no. $8 \mathrm{1} 6 ; 3$ Bravard-Veyrières, Traité de droit commercial (2d ed. by Demangeat) 418; 4 Lyon-Caen \& Renault, Traité de droit commercial (4th ed.) no. 36r; Nouguier, Des lettres de change (4th ed.) nos. 1107-1108; Pandectes françaises, Effets de commerce, nos. 2463 et seq.; Pardessus, Contrat de change, 
Italy, ${ }^{14}$ Norway, Sweden, ${ }^{15}$ and in many of the Swiss cantons. ${ }^{16}$ - In certain countries, on the other hand, the defense of vis major was not and is not recognized to-day in the law of bills and notes. In these countries it is deemed good commercial policy to guarantee to a drawer or indorser of a bill or note an absolute protection against liability upon the instrument ${ }^{17}$ after the expiration of the period fixed by law for presentment, protest and notice. The fact that such steps may have been delayed or rendered impossible by an act of God or other circumstances beyond the control of the holder within the exercise of reasonable diligence is of no consequence. Such is still the law in Germany. ${ }^{18}$ By a law of Apr. I3, I9I4, ${ }^{10}$ it was enacted that the government with the assent of the Federal Council might decree, if the due presentment or protest in a foreign country was prevented by a legal prohibition, that such act might be done immediately after the removal of such obstacle or that recourse might be taken after a certain time without the necessity of presentment or

no. 366; I Cours de droit commercial, no. 426; Ruben de Couder, Dictionnaire, Protêt, nos. 62 et seq.; Thaller, Traité élémentaire de droit commercial, 774

${ }^{13}$ Art. 202, Commercial Code, according to which any delay caused by "an unforeseen circumstance or vis major" is excused if the bill of exchange was forwarded in time.

${ }^{14}$ Cass. Turin, Mar. 6, 1872, Annali, I872, I, 107; Monitore, I872, p. 234; Cass. Florence, June 16, 1873, Annali, 1873, r, 47. Some of the text-writers contend that the recognition of vis major is inconsistent with the underlying theory of the Italian law of bills and notes. Ottolenghi, La cambiale nel diritto internazionale, 399; 3 Vivante, Trattato di diritto commerziale (3d ed.) no. I3I7. Contra: Supino, Della cambiale, no. 349; 7 Vidari, Corso di diritto commerziale (4th ed.) no. $7030 ; 9$ Archivo giuridico, r9r.

${ }^{15}$ Sec. 92 of the Bills of Exchange Law of Sweden, which apparently reennacts the former law. See I Grünhut, Wechselrecht, 192, note 69.

${ }^{26}$ Fick, 53; Munzinger \& Riggeler, I7 Goldschmidt's Zeitschrift, 299.

${ }^{27}$ Although the drawer or indorser is discharged from his liability on the instrument, he may be liable in quasi-contracts so far as he is unjustly enriched. Art. 83, German Bills of Exchange law; I Meyer, I6I-I64.

${ }^{18}$ Einert, I Archiv für das deutsche Wechselrecht, 227; Bernstein, Allgemeine deutsche und österreichische Wechselordnung, 202; Borchardt, Die allgemeine deutsche Wechselordnung, 47I, note; Goldschmidt, Grundxiss des Handelsrechts, 229; I Meyer, Weltwechselrecht, 9I; Rehbein, Wechselrecht, art. 4I, n. 8; Staub, Wechselrecht, art. 4r, no. 3; Wächter, Das Wechselrecht des deutschen Reichs, 354, 377.

$V$ is major can be set up to-day only in connection with the prescription of actions pursuant to sec. 203 of the Civil Code which has become applicable with the repeal of art. 90 of the German Bills of Exchange Law. See Staub, Wechselrecht (ed. by Stranz) art. 79, no. 2I ; I Meyer, Weltwechselrecht, 9I. Contra: 2 Dernburg, Lehrbuch des bürgerlichen Rechts und Preussens, sec. 277, p. 325.

The defense of vis major was recognized before the introduction of the Bills of Exchange Law of I849. 2 Treitschke, Encyclopädie des Wechselrechts, "Versendung," pp. 620-622.

${ }^{10}$ Reichsgesetzblatt, 1914, p. 107. 
protest. Such a decree was made on Aug. 7, I9I4. ${ }^{20}$ It provided that in the above cases presentment or protest might be made within six days after the expiration of such prohibitive legislation. A law of Aug. 4, $1914,{ }^{21}$ had already provided for such an extension if presentment or protest was rendered impossible either because the place where the act was to be done was occupied by the enemy or because a regular postal service no longer existed. On Aug. 29, the period of six business days referred to in the law of Aug. 4 was extended to two weeks. ${ }^{22}$

In Austria also, although the juristic opinion was not so settled as in Germany, the prevailing view has, been that the defense of vis major was inconsistent with the requirements of the exchange law. ${ }^{23}$ The Austrian law was changed, however, by legislative enactment of Nov. $30,1912,{ }^{24}$ which provided that when the presentment and protest were prevented by insurmountable obstacles the time for presentment and protest should be extended. According to this law the holder is to notify his indorser immediately of the existence of vis major and to indicate the fact on the bill or an allonge. If the vis major lasts longer than thirty days after the maturity of the instrument, recourse may be taken without the necessity of presentment or protest. In the case of bills payable at sight or after sight the period of thirty days is to begin to run from the date on which the holder has notified the indorser of the existence of vis major. Laws affecting exclusively the person of the holder or the party entrusted with the presentment of the bill or note or with the drawing of the protest are not to be regarded as cases of vis major. In this latter respect the law follows art. 53 of the Uniform Law of the Convention of the Hague of ror 2 relating to bills and notes.

The defense of vis major was formerly disallowed in certain of the Swiss cantons ${ }^{25}$ including the canton of Zurich. ${ }^{28}$ Through the general law of obligations (art. 813), which is now a part of the Swiss Civil Code, such prohibition has become the general Swiss law. At the outbreak of the European war the law was modified by a decree of the Federal Council, adopted on Sept. I, I9I4, to the effect that, if presentment or protest in a foreign country is prevented by legisla-

${ }^{00}$ Reichsgesetzblatt, I914, p. 387; I Kriegsnotgesetze, I26; 76 Goldschmidt's Zeitschrift, 508.

${ }^{21}$ Reichsgesetzblatt, I9r4, p. 327; I Kriegsnotgesetze, 19; 76 Goldschmidt, 480.

${ }^{2}$ Reichsgesetzblatt, I9I4, p. 387; I Kriegsnotgesetze, 126; 76 Goldschmidt, 508.

${ }^{23}$ Blaschke, Das österreichische Wechselrecht (7th ed.) 265-266; Aussez, Oesterreichische Gerichtszeitung, I852, no. 31, p. r22; Canstein, Wechselrecht, 328; 2 Grünhut, Wechselrecht, 397; 1 Meyer, Weltwechselrecht, 9I-92.

${ }^{34}$ Reichsgesetzblatt, Igr2, no. 2r5.

${ }^{25}$ Fick, 53; Munzinger \& Riggeler, I7 Goldschmidt, 299.

${ }^{20}$ Decision of Commercial Court of Zurich, of May 22, I87x, 22 Zeitschrift für Kunde und Fortbildung der zürcherischen Rechtspflege, 371. 
tion prohibiting such act or by any other case of vis major arising out of the state of war, the holder's rights should be preserved notwithstanding such omission if the act is done within six business days after the removal of such obstacle. ${ }^{27}$

The defense of vis major appears to have been prohibited in Russia by a law of May 29 , I902. ${ }^{28}$

\section{APPENDIX D}

SPECIAL LITERATURE ON MORATORY LEGISLATION AND THE CONFLICT OF LAWS

I

Barrault: L'application en droit international de la législation de la guerre (moratorium). Revue de droit international privé, I9I6, $\mathrm{p}$. 572; I9I7, p. I4I.

Buscemi, S.: Sovra un caso di decadenza dall' azione di regresso in materia cambiari. 8 Archivo gintidico, 83.

Cambon, C.: Ancora sugli effetti del moratorio francese rispetto ai diritti di regresso del portatore. 5 Gazetta dei tribunali, I871, n. I3.

Esperson, P.: Proroga della scadenza delle cambiali in Sicilia. Monitore dei tribunali, I894, I2I.

Fick, H.: Ueber internationales Wechselrecht in Beziehung auf Fristbestimmungen, insbesondere die französischen Wechsel-Moratoriums-Gesetze und Dekrete. Reprint of Centralorgan fïr das deutsche Handels- und Wechselrecht, N. S. vol. 7, p. I67; vol. 8, p. I29.

Ghiron: Moratorie e regressi nel diritto internazionale privato. Rivista di diritto internazionale, I9I5, P. I52.

Giuseppe, R.: Della forza maggiore nel diritto cambiario internazionale. (Turin, I87x.)

Götze, H.: Das französische Wechsel-Moratorium und seine Rechtswirkung in Oesterreich. Allgemeine österreichische Gerichtszeitung, I87x, n. 42 , p. I65.

Hovy, M. A. J.: Jets over de gevolgen der Fransche wet van I3 Augustus 1870 met betrekking tot de wisselverbindtenissen buiten Frankrijk aangegaan. Magazijn van handelsregt, I871. Mengelinen, 43 .

Jacques, H.: Die durch die französischen Moratorienverfïgungen hervorgerufenen Regressfragen. Allgemeine österreichische Gerichtszeitung, I871, n. 99-104, pp. 393, 397, 40r, 405, 409, 4I3.

Kist, J. G.: Het Arrest van het Duitsche Oberhandelsgericht, betrekkelijk den invloed der Fransche wet von I3 Augustus I870 op

${ }^{2 \pi}$ Amtliche Sammlung der Bundesgesetze und Verordnungen, I9r4, p. 423.

${ }^{2}$ See Despagnet (5th ed. by de Boeck) 996 . The writer could not verify this statement. He has also been unable to ascertain the legislation that may have been passed with reference to the subject by Russia during the present war. 
niet-Fransche wisselverbindtenissen. Themis, regtskundig tijdschrift, I872, vol. 33, p. 20.

Keyssner, H.: Das Erkenntnis des Bundes-Oberhandelsgerichts vom 21 Februar d. J. und die Petitionen um Deklaration des Art. 86 der Allg. Deutschen Wechselordnung. Deutsches Handelsblatt, I87r, n. I6.

Ladenburg: Welchen Einfluss hat die ausländische Gesetzgebung beziiglich der Zeit der im Auslande aufzunehmenden Proteste. Centralorgan fïr das deutsche Handels- und Wechselrecht, N. S. vol. 7, p. 287 .

Lebano, V.: Della prorogá dei termini del protesto per le cambiali pagabili in Francia e del regresso contro $i$ giranti ed $i$ traenti. 5 La temis italiana. Giornale di legislazione e giurisprudenza, $\mathrm{n}$. I7, I8. (Naples, I87r.)

Lyon-Caen, Ch.: Des conséquences de la prorogation des échéances des effets de conmerce, édictée à raison de la guerre dans les rapports des porteurs avec les endosseurs et tireurs des pays étrangers. Clunet, I9I7, p. 400.

Lyon-Caen, Ch.: Note in Belgique Judiciaire, I873, col. 568.

Munzinger and Riggeler: Rechtsgutachten, betreffend die durch die prorogirenden Gesetze und Dekrete der französischen Behörden hervorgerufenen Regressfragen, verfasst im Auftrage des Tit. Schweizerischen Handels- und Zolldepartements. Bern, I87I.

Norsa, C.: Sul conflitto internazionale delle varie legislazioni interno alle lettere di cambio, e sulla condizione giuridica de' possessori d'effetti commerciali tratti sulla Francia da huoghi esteri, e pagabili in Francia durante la guerra franco-prussiana, ed il moratorio stabilito dalle leggi e dai decreti del Governo francese. Monitore dei tribunali, I87I, nos. I8-22, pp. 329, 369, 409.

Salpius: Ueber die Anwendung ausländischen Rechtes auf den Wechselregress. Ig Zeitschrift fïr das gesamte Handelsrecht, I.

Saredo, G.: La proroga dei termini del protesto per le cambiali pagabili in Francia, ha essa efficacia contro $i$ traenti ed $i$ giranti italiani. La Legge, I872, I, 385 .

Swoboda, J.: Das französische Gesetz von I3. August, I870, ïber die Prorogation der Protestpflicht für negotiable Werthpapiere. Allgemeine österreichische Gerichtszeitung, I870, pp. 289, 293, 297, 301. Ueber die Bedeutung und Rechtswirkung der sogenannten Wechselprolongation, I6 Archiv für deutsches Wechsel- und Handelsrecht, 29.

Van Raalte, E. E.: De schorsing van het wisselprotest in Frankrijk gedurende den oorlog van 1870 en haar gevolgen voor buitenlandsche garanten. (Rotterdam, I87I.)

Vidari, E.: Sovira un caso di decadenza dall' esercizio dell' azione di regresso in materia cambiaria. 7 Archivo giuridico, 263. 
La sentenza del 6 Marzo 1872 della corte di cassazione sedente in Torino. 9 Archivo giuridico, 187.

Note with reference to Italian moratory decrees of Jan. 5 and 8, I894, Monitore dei tribunali, I894, p. 99.

$X$, Reply to Vidari with respect to moratory decrees of Jan. 5 and 8, I894. Monitore dei tribunali, I894, p. 99.

Wächter, L.: Zur Kritik des Schweizer Gutachtens über die durch die französischen Prorogationsgesetze hervorgerufenen Regressfragen. 4 Archiv für deutsches Wechselrecht und Handelsrecht, N. S. I.

II

The question is also discussed in the following works:

Audinet: Principes élémentaires de droit international privé (ad ed.) n. 754 .

Bar, L. von: Private International Law (transl. by Gillespie) 682. Internationales Handelsrecht, in I Ehrenberg, Handbuch des gesamten Handelsrechts, I9I3, p. 394.

Bolaffio, L.: Esegesi dell Art. $5^{8}$ del Codice de commer̂rcio italiano (diritto internazionale privato commerciale). 23 Rivista italiana per le scienze giuridiche, I897, p. 2I7.

Champcommunal, J.: Etude sur la lettre de change en droit international privé. Annales de droit commercial, I894, pt. 2, 249.

Chrétien, A.: Etude sur la lettre de change en droit international privé (Nancy, I88I) I86.

Despagnet, F.: Précis de droit international privé (5th ed. by de Boeck, Paris, I909) n. 346.

Diena, G.: 3 Trattato di diritto commerciale internazionale (Florence I905) I85.

Goldschmidt, L.: System des Handelsrechts (4th ed. 1892) 268.

Jitta, J.: 2 La substance des obligations, I39.

Lyon-Caen \& Renault: 4 Traité de droit commercial (4th ed. Paris I907) 568.

Meili, F.: 2 Das internationale Civil- und Handelsrecht, 351. International Civil and Commercial law (transl. by A. K. Kuhn, New York 1905) 506.

Ottolenghi, G.: La cambiale nel diritto internazionale (Turin, I902) $43^{\text {I. }}$

Ramella, A.: I Trattato dei titoli all' ordine (Florence I899) 456.

Rolin, A.: 2 Principes du droit international privé, $55 \mathrm{I}$.

Weiss, A.: 4 Traité de droit international privé (2d ed.) 465. 